\title{
A UTILIZAÇÃO DO MÍNIMO EXISTENCIAL COMO CRITÉRIO DE EXIGIBILIDADE JUDICIAL DOS DIREITOS FUNDAMENTAIS ECONÔMICOS E SOCIAIS: REFLEXÕES CRÍTICAS
}

\author{
THE USE OF EXISTENTIAL MINIMUM AS A CRITERION OF JUDICIAL \\ ENFORCEABILITY OF FUNDAMENTAL ECONOMIC AND SOCIAL RIGHTS: \\ CRITICAL REFLECTIONS
}

Daniel Wunder Hachem ${ }^{1}$

\begin{abstract}
Resumo: O presente trabalho tem por objetivo examinar, sob uma perspectiva crítica, a utilização da noção de mínimo existencial como um critério determinante para delimitar a exigibilidade judicial dos direitos fundamentais econômicos e sociais. Para tanto, busca-se precisar o significado jurídico conferido ao conceito, perpassando pela análise de suas origens, natureza e fundamentos jurídicos, estrutura normativa, relação com os direitos fundamentais econômicos e sociais, para demonstrar que a doutrina e a jurisprudência brasileiras têm se valido do mínimo existencial de maneiras distintas e com propósitos diferenciados. Ao longo do estudo, são apresentados alguns caminhos e posicionamentos voltados a um emprego funcional do conceito, demonstrando a impossibilidade de utilizá-lo como critério definitivo para delinear a exigibilidade judicial dos direitos fundamentais sociais.
\end{abstract}

Palavras-chave: direitos econômicos e sociais; direitos fundamentais; exigibilidade judicial; jusfundamentalidade; mínimo existencial.

Abstract: This study aims to examine, from a critical perspective, the use of the notion of existential minimum as a criterion for defining the judicial enforceability of fundamental economic and social rights. It seeks to clarify the juridical meaning given to the concept, passing by analyzing its origins, nature and legal foundations, normative structure, relation with the fundamental economic and social rights, to demonstrate that the Brazilian doctrine and jurisprudence have been using the existential minimum in different ways and with different purposes. Throughout the study, we present some ways and positions focused on a functional employment of the concept, demonstrating the impossibility of using it as a definitive criterion to delineate the judicial enforceability of fundamental social rights.

Keywords: economic and social rights; fundamental rights; judicial

\footnotetext{
1 Doutorando e Mestre em Direito do Estado pela Universidade Federal do Paraná. Professor do Departamento de Direito Público da Universidade Federal do Paraná. Editor Acadêmico da A\&C - Revista de Direito Administrativo \& Constitucional. Advogado. E-mail: danielhachem@gmail.com
} 


\section{CONSIDERAÇÕES INICIAIS: $O$ MÍNIMO EXISTENCIAL E A JUSFUNDAMENTALIDADE DOS DIREITOS ECONÔMICOS E SOCIAIS}

O regime jurídico dos direitos econômicos e sociais ${ }^{2}$ no Direito Constitucional brasileiro consiste em ponto de divergência tanto no âmbito doutrinário quanto na seara jurisprudencial. A aceitação de que tais direitos se configuram como legítimos direitos fundamentais, e que portanto se submetem à disciplina jurídica especial que a Constituição dispensa a esses direitos, não foi e ainda não é um ponto de unanimidade da teoria dos direitos fundamentais. A temática, mais do que simples análise jurídica do texto constitucional, remonta a questões de fundamentação dos direitos humanos e fundamentais, visto que as variadas posições contrárias ao reconhecimento da jusfundamentalidade dos direitos econômicos e sociais baseiam-se não somente em um prisma dogmático, mas também, conforme identifica Gerardo Pisarello, em percepções históricas, filosófico-normativas e teóricas. ${ }^{3}$

$\mathrm{Na}$ sistemática constitucional brasileira, o reconhecimento de que determinados direitos são dotados de fundamentalidade impõe a identificação de um regime jurídico determinado, sobre eles incidente. Isso porque, muito embora não se possa afirmar a existência um sistema autônomo e fechado de direitos fundamentais na Constituição brasileira, completamente afastado do contexto geral da Lei Maior, é possível, ao menos, perceber elementos normativos distintivos que emprestam a esses direitos uma disciplina jurídica peculiar. Assim como os demais direitos previstos pela Constituição Federal, os direitos fundamentais consistem em direitos supralegais, eis que veiculados por

\footnotetext{
2 Destaque-se, desde logo, que neste texto as expressões "direitos sociais", "direitos econômicos e sociais" e "direitos fundamentais sociais" serão utilizadas indistintamente, para designar os direitos fundamentais que têm por objeto a tutela de bens econômicos, sociais e culturais imprescindíveis para assegurar uma vida digna, que o indivíduo poderia obter também dos particulares, caso ostentasse condições financeiras para adquiri-los e os encontrasse disponíveis no mercado. Sobre a caracterização de tais direitos a partir do conteúdo mencionado, ver: ALEXY, 2007, p. 443; NOVAIS, 2010, p. 41.

${ }^{3}$ Para uma análise das teses contrárias ao reconhecimento de jusfundamentalidade aos direitos sociais sob as perspectivas histórica (p. 19-36), filosófico-normativa (p. 37-58), teórica (p. 59-78) e dogmática (p. 79-110), ver: PISARELLO, 2007.
} 
normas constitucionais situadas no ápice da ordem jurídica, insuscetíveis de modificação simples pelo legislador ordinário. No entanto, há pelo menos dois caracteres que peculiarizam o regime jurídico dos direitos fundamentais, não se estendendo a todos os direitos constitucionalmente estabelecidos (SARLET, 2010, p. 74-75): a aplicabilidade imediata (art. 5ำ $§ 1^{\circ}$, CF) e a proteção contra emendas abolitivas (art. 60, $\left.4^{\circ}{ }^{\circ}, \mathrm{IV}, \mathrm{CF}\right) .^{4}$

O primeiro deles consiste na previsão do art. $5^{\circ}, \S^{\circ} \stackrel{\circ}{ }$ da $C F$, a qual dispõe que "As normas definidoras dos direitos e garantias fundamentais têm aplicação imediata". Trata-se de inovação da Constituição de 1988, não incluída em textos constitucionais pretéritos, e que enseja variadas interpretações da doutrina em torno do seu comando normativo. ${ }^{5}$ Há consenso, contudo, no sentido de que a determinação tem o condão de estabelecer que todas as disposições que consagram direitos e garantias fundamentais vinculam diretamente os Poderes Públicos (Executivo, Legislativo e Judiciário), sendo capazes de gerar efeitos jurídicos desde logo, independentemente de regulamentação infraconstitucional (ainda que não haja unanimidade quanto às espécies de direitos englobados por esse dispositivo e quanto à extensão desses efeitos).

A previsão surge como forma de superar a ideia de que os direitos fundamentais só ganham operatividade após serem enunciados pelo legislador ordinário, intelecção própria da racionalidade vigente na Europa continental do século XIX, em que a proteção dos direitos fundamentais se resumia no respeito ao princípio da legalidade por parte da Administração. A garantia dos direitos fundamentais residia na existência de uma lei regulamentadora, cujo conteúdo dirigia-se à tutela do cidadão frente às intervenções do Poder Executivo contra a liberdade e a propriedade. Logo, não havia uma vinculação direta do legislador ao conteúdo do texto constitucional ou das declarações de direitos (GAVARA DE CARA, 1994. p. 9-10). No contexto específico do Brasil, a afirmação expressa de que as normas de direitos fundamentais são

\footnotetext{
${ }^{4}$ Acolhe-se aqui a posição de Sarlet, de que "A condição de 'cláusula pétrea', aliada ao

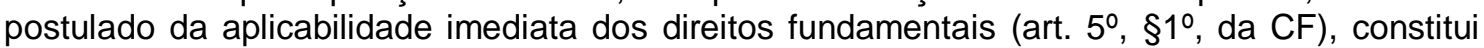
justamente elemento caracterizador essencial de sua força jurídica reforçada na ordem constitucional pátria" (2010, p. 422).

5 Para uma análise das distintas posições acerca da interpretação do art. $5^{\circ}$, $\S^{\circ} \stackrel{ }{ }$ da Constituição Federal, entre outros, ver: HACHEM, 2008.
} 
imediatamente aplicáveis decorre também da existência habitual de disposições insertas em Constituições anteriores que jamais chegaram a sair do papel. ${ }^{6}$

O segundo elemento acima referido concerne à vedação de emendas constitucionais que tendam a eliminar direitos fundamentais da ordem jurídica, nos termos do art. $60, \$ 4^{\circ}$, IV da CF: "Não será objeto de deliberação a proposta de emenda tendente a abolir: (...) os direitos e garantias individuais". Por conta desse dispositivo, os direitos fundamentais integram as chamadas cláusulas pétreas, constituindo limites materiais à reforma da Constituição. Há aqui, igualmente, controvérsias quanto ao âmbito de incidência do mandamento em questão, notadamente pelo fato de o constituinte ter utilizado a expressão "direitos e garantias individuais", em vez de "direitos e garantias fundamentais", fato que, para alguns, implicaria excluir do seu espectro os direitos econômicos e sociais (MAGANO, 1994, p. 110-111).

Nessa medida, pode-se dizer que o sistema constitucional brasileiro instituiu um regime jurídico especialmente protetivo aos direitos fundamentais, tutelando-os de modo diferenciado em uma dupla perspectiva: (i) em um sentido negativo, blindando-os contra ações ofensivas do Poder Constituinte Reformador, ao proibir a edição de emendas constitucionais tendentes a aboli-

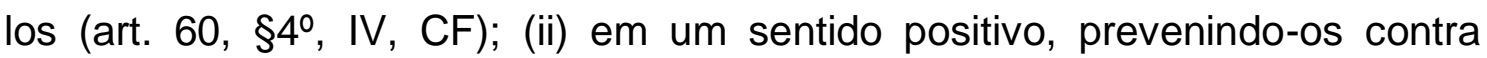
omissões atentatórias do legislador, do administrador e do juiz, ao determinar

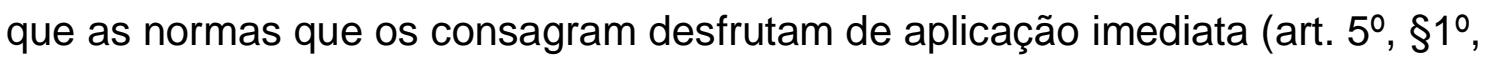
CF). Cuida-se, pois, de um regime que, de um lado, assegura a proteção contra investidas de maiorias parlamentares que pretendam vergastar 0 conteúdo dos direitos fundamentais, eliminando-os da Constituição, e de outro, impulsiona a promoção efetiva desses direitos quando a inércia - intencional ou não - do Poder Público inviabilizar o seu exercício por omissão na sua regulamentação normativa ou na sua implementação material.

Conforme mencionado, há na doutrina brasileira acirrada divergência quanto aos direitos que estão submetidos a esse regime jurídico específico. É

\footnotetext{
${ }^{6}$ É o caso da Emenda Constitucional no 1/1969, que em seu art. 165, XVIII assegurava aos trabalhadores, apenas em tese, direitos sociais como "XVIII - colônias de férias e clínicas de repouso, recuperação e convalescença, mantidas pela União, conforme dispuser a lei”, os quais jamais foram concretizados (BARROSO, 2005, p. 63).
} 
possível identificar ao menos quatro posições a respeito desse tema: (a) exclusão dos direitos econômicos e sociais do âmbito de proteção do regime jurídico dos direitos fundamentais; ${ }^{7}$ (b) limitação da aplicação do regime jurídico dos direitos fundamentais ao conteúdo dos direitos econômicos e sociais coincidente com o mínimo existencial (TORRES, 2003; MAURÍCIO JR., 2009, p. 47); (c) incidência do regime jurídico dos direitos fundamentais somente sobre a parcela dos direitos econômicos e sociais necessária a garantir as condições procedimentais da democracia (SOUZA NETO, 2002, p. 17-61; e 2008, p. 515-551); (d) submissão integral dos direitos econômicos e sociais ao regime jurídico dos direitos fundamentais (SARLET, 2010; NOVAIS, 2010).

Nada obstante a existência dessas várias concepções acerca da jusfundamentalidade dos direitos econômicos e sociais, tem sido comum no Direito brasileiro, tanto na doutrina quanto na jurisprudência, a referência ao conceito de mínimo existencial quando se trata do tema da exigibilidade judicial dos direitos sociais. Percebe-se, especialmente nas decisões judiciais, que mesmo os intérpretes que não adotam expressamente a redução o caráter de fundamentalidade dos direitos econômicos e sociais ao mínimo existencial, muitas vezes a ele recorrem com o propósito de reforçar seus argumentos em prol da satisfação judicial de prestações materiais positivas, manejando o conceito sem precisão teórica e confundindo o seu conteúdo com o dos direitos sociais.

A intenção deste estudo é, pois, analisar de maneira um pouco mais aprofundada a tratativa doutrinária e jurisprudencial acerca do direito ao mínimo existencial, perquirindo a sua formulação conceitual e esclarecendo a sua relação com os direitos fundamentais sociais, para delinear com maior clareza as distinções e os pontos de contato entre eles. Objetiva-se, com isso, contribuir para a diminuição do emprego indiscriminado da categoria do mínimo existencial, cada vez mais comum no Brasil, ora para o propósito de nele inserir toda e qualquer prestação vinculada a um direito fundamental social, ora para

\footnotetext{
${ }^{7}$ É o caso de autores como Octávio Bueno Magano, quando admite a possibilidade de exclusão de direitos sociais da Constituição brasileira por meio de reformas constitucionais (1994, p. 110-111), e de João Pedro Gebran Neto, quando nega a submissão dos direitos sociais ao regime de aplicabilidade imediata das normas definidoras de direitos fundamentais, previsto no art. $5^{\circ}$, $\S^{1}{ }^{\circ}$ da Constituição Federal (2002, p. 158).
} 
justificar a rejeição de realização judicial de direitos fundamentais sociais, sob o argumento de não estarem nele incluídos.

Destaque-se, desde logo, que não se pretende esgotar o assunto, investigando as raízes filosóficas do conceito, todas as suas possíveis fundamentações ${ }^{8}$ e os seus diversos desdobramentos jurídicos ${ }^{9}$. O escopo limita-se ao tema central do estudo, que diz respeito às relações do mínimo existencial com a jusfundamentalidade dos direitos econômicos e sociais.

\section{ORIGENS, CONCEITO E FUNDAMENTOS JURÍDICOS DO MÍNIMO EXISTENCIAL}

A noção de mínimo existencial pode ser analisada tanto sob o prisma negativo, da defesa do indivíduo contra intervenções estatais que dele subtraiam os meios essenciais para sua sobrevivência com dignidade, quando sob a óptica positiva, relativa à necessidade de prestações do Poder Público destinadas a propiciar condições materiais de existência digna.

Enfrentando o tema sob ambas as perspectivas, Ricardo Lobo Torres sintetiza a problemática do mínimo existencial relacionando-a com a questão da pobreza e da cobrança de tributos pelo Estado. Com a superação do Estado Patrimonial, em que a classe pobre da população estava sujeita ao pagamento de tributos, no Estado de Polícia inicia-se a previsão da imunidade do mínimo existencial, afastando do âmbito de incidência fiscal as pessoas destituídas de condições financeiras mínimas para a sua subsistência. No Estado Fiscal de Direito amplia-se a imunidade do mínimo existencial em relação aos impostos, aliada à teoria da tributação progressiva, estendendo-se também às taxas, admitindo-se prestações estatais positivas (educação, assistência médica, etc.) independentemente de contrapartida pecuniária. E no Estado Social Fiscal,

\footnotetext{
${ }^{8}$ Sobre os fundamentos teóricos e filosóficos do mínimo existencial, explorando de forma aprofundada as distintas concepções de John Rawls ("defesa do mínimo social"), Friedrich Hayek ("garantia de uma renda mínima"), Michael Walzer ("proteção universal e comunitária de direitos mínimos"), Jürgen Habermas ("a autonomia requer direitos básicos") e Carlos Santiago Nino ("condições materiais decorrentes da autonomia"), ver: HONÓRIO, 2009, p. 12-41. Para uma análise mais sintética das fundamentações de John Rawls, Robert Alexy, Jürgen Habermas e Phillipe Van Parijs: TORRES, 2009, p. 54-62. O tema foi também explorado por: BARCELLOS, 2002.

9 Para uma análise completa do mínimo existencial e de seus diversos desdobramentos jurídicos, ver: TORRES, 2009, p. 179-298.
} 
correspondente à fase do Estado de Bem-Estar Social, a proteção deixa de limitar-se ao mínimo existencial, alargando-se no sentido de impor ao Estado mecanismos paternalistas de proteção dos direitos sociais (TORRES, 2009, p. 3-7).

Sob o prisma positivo, referente ao dever estatal de implementar prestações materiais aos necessitados, costuma-se afirmar que 0 reconhecimento pioneiro de um direito fundamental às condições mínimas de existência digna deu-se jurisprudencialmente na Alemanha, onde teve a sua "primeira importante elaboração dogmática" (SARLET; FIGUEIREDO, 2010, p. 20). De acordo com Ingo Sarlet, o primeiro jurista alemão no período PósGuerra a identificar um direito ao mínimo existencial foi Otto Bachof. A formulação baseava-se no princípio da dignidade humana, partindo da idéia de que a sua realização plena não dependia apenas da salvaguarda da liberdade, mas, igualmente, de um mínimo de segurança social, uma vez que o indivíduo despido de recursos materiais que lhe permitissem viver adequadamente não teria sua dignidade respeitada. Um ano depois da formulação do citado autor tedesco, em 1954, o Tribunal Federal Administrativo alemão (Bundesverwaltungsgericht) reconheceu a um cidadão carente o direito subjetivo a recursos materiais propiciados pelo Estado, ${ }^{10}$ lastreando-se no princípio da dignidade humana, e nos direitos à vida e à liberdade (HONÓRIO, 2009, p. 45-46). No ano de 1975, o Tribunal Constitucional Alemão reconheceu, também, a existência do direito ao mínimo para uma existência digna como direito fundamental do cidadão. ${ }^{11}$

O contexto constitucional alemão deve ser esclarecido, para uma adequada compreensão do seu pioneirismo no reconhecimento jurisprudencial do direito ao mínimo existencial. A Constituição alemã - Lei Fundamental de Bonn de 1949 - não prevê um rol expresso de direitos sociais típicos, afora a

\footnotetext{
${ }_{11}^{10}$ ALEMANHA. BVerwGE 1, 159 (161 e ss.), 24.06.1954.

11 Observe-se trecho da decisão: "certamente a assistência aos necessitados integra as obrigações essenciais de um Estado Social. [...] Isso inclui, necessariamente, a assistência social aos cidadãos que, em virtude de sua precária condição física e mental, encontram-se limitados nas suas atividades sociais, não apresentando condições de prover a sua própria subsistência. A comunidade estatal deve assegurar-lhes pelo menos as condições mínimas para uma existência digna e envidar os esforços necessários para integrar estas pessoas na comunidade, fomentando seu acompanhamento e apoio na família ou por terceiros, bem como criando as indispensáveis instituições assistenciais". A tradução foi extraída de SARLET, 2010, p. 318.
} 
proteção da maternidade e dos filhos, bem como o dever de atuação estatal em prol da compensação das desigualdades fáticas relativas à discriminação das mulheres e dos portadores de deficiências (embora alguns sequer considerem estes como direitos sociais) (SARLET; FIGUEIREDO, 2010, p. 20). Assim, não há na Alemanha, tal como existe no Brasil, um rol sistemático de direitos sociais como saúde, educação, assistência social, etc., fato que alguns autores reputam à má experiência da Constituição de Weimar de 1919. Segundo Andreas J. Krell, para os alemães, sua Constituição anterior - reconhecida internacionalmente como uma das pioneiras, juntamente com a Constituição mexicana de 1917, na incorporação de direitos sociais - é encarada como um modelo "fracassado", que inclusive contribuiu para a tomada de poder pelos nazistas (2002, p. 45).

Essa ausência de direitos sociais na Constituição alemã contribuiu para uma certa convergência doutrinária em torno da ideia de que o Estado deve garantir aos cidadãos um "mínimo social", entendendo-se que seria possível extrair, diretamente da Lei Fundamental e independentemente de previsão legislativa, um direito subjetivo originário a prestações que proporcionem condições mínimas de existência digna. Não se trataria de um nível otimizado de prestações condizentes com a justiça distributiva exigível em um Estado Social, mas tão-somente de um mínimo necessário à proteção da dignidade humana e das satisfações elementares imprescindíveis para o exercício das liberdades fundamentais. $E$ foi com base nisso que os mencionados tribunais reconheceram, de forma pioneira, o direito ao mínimo existencial, alicerçado nos princípios da dignidade da pessoa humana, do Estado Social e no direito à vida (NOVAIS, 2010, p. 80-81). Posteriormente, outras Cortes Constitucionais proferiram importantes decisões concedendo o direito ao mínimo para uma existência digna, ${ }^{12}$ mesmo em ordenamentos jurídicos que consagram direitos fundamentais sociais em suas Constituições.

\footnotetext{
12 Para uma evolução do reconhecimento do direito ao mínimo existencial pelo Tribunal Constitucional português, com referências aos diversos acórdãos que trataram do tema, desde 1983 (à época "Comissão Constitucional portuguesa", posteriormente substituída pelo Tribunal Constitucional), conferir: BITTENCOURT NETO, 2010, p. 92-96. Sobre a identificação do referido direito na jurisprudência colombiana: ARANGO; LEMAITRE, 2000. Referências sobre a jurisprudencia do Tribunal Constitucional espanhol a propósito da matéria podem ser encontradas em: MARÍN-BARNUEVO FABO, 1996, p. 51 et seq.
} 
Observadas as origens do direito ao mínimo existencial, insta examinar o seu conceito. Consoante Ricardo Lobo Torres, ele pode ser definido como "um direito às condições mínimas de existência humana digna que não pode ser objeto de intervenção do Estado na via dos tributos (= imunidade) e que ainda exige prestações estatais positivas" (2009, p. 35). Como dito linhas atrás, do ponto de vista negativo ele impede investidas do Poder Público que visem a subtrair do indivíduo os meios necessários a assegurar a sua subsistência com dignidade. Sob a óptica positiva, ele corresponde, nas palavras de Ana Paula de Barcellos, ao "conjunto de situações materiais indispensáveis à existência humana digna; existência aí considerada não apenas como experiência física a sobrevivência e a manutenção do corpo - mas também espiritual e intelectual", que permita a participação democrática dos cidadãos nas esferas de deliberação pública, possibilitando-lhes o livre desenvolvimento de sua personalidade (2011, p. 247).

Seu conteúdo encontra-se intimamente ligado com o do princípio da dignidade da pessoa humana. Embora com diferentes graus de vinculação, a dignidade da pessoa humana, na condição de valor e princípio normativo fundamental, atrai o conteúdo dos direitos fundamentais (SILVA, 1998, p. 92), exigindo e pressupondo o reconhecimento e proteção de todas as espécies de direitos fundamentais (SARLET, 2006, p. 85). Há uma relação de complementaridade entre as chamadas gerações ou dimensões de direitos fundamentais, já que os direitos individuais, civis e políticos, requerem a garantia de condições materiais mínimas para o seu exercício, proporcionadas pelos direitos econômicos e sociais, de modo que todos conjuntamente promovem a dignidade humana. ${ }^{13}$ Por conseguinte, do princípio da dignidade humana derivam, concomitantemente, a obrigação de não-violação e o dever de promoção e proteção.

No entanto, conquanto a dignidade humana possa ser promovida em maior ou menor grau, conforme a intensidade da proteção aos direitos fundamentais, é possível identificar uma linha abaixo da qual não há dignidade, que pode decorrer não de uma violação ativa, mas omissiva, por parte do

\footnotetext{
${ }^{13}$ Tome-se, como exemplo, o direito à liberdade de expressão, que só poderá ser plenamente exercido se o seu titular souber e puder ler e escrever, gozando respectivamente dos direitos à educação e à saúde, dentre outros.
} 
Estado, de proporcionar ao indivíduo garantias mínimas de existência digna. Do mesmo modo como há um consenso social em relação ao desrespeito à dignidade provocado por determinadas ações ( $v . g$., prática de tortura), deve haver um consenso social acerca da transgressão do mesmo princípio quando a omissão do Poder Público importar uma situação de flagrante indignidade. É disso que se trata o mínimo existencial: do "núcleo material do princípio da dignidade humana", o qual, quando desrespeitado pela negligência estatal, gera uma violação consensual da dignidade do ser humano (BARCELLOS, 2011, p. 247 e 243).

Isso não significa que o direito em questão limite-se à garantia de uma simples sobrevivência física (mínimo fisiológico), ou seja, ao combate à pobreza absoluta. Ele deve compreender não apenas prestações que possibilitem a mera existência, mas também a fruição dos demais direitos fundamentais e o livre desenvolvimento da personalidade do seu titular. Nesse influxo, ele englobaria também o chamado mínimo existencial sociocultural, que além de assegurar a satisfação das necessidades básicas para a sobrevivência individual (fundamentando-se no direito à vida), possibilita ainda a inserção do cidadão na vida social (lastreando-se nos princípios do Estado Social e da igualdade material). ${ }^{14} \mathrm{O}$ mínimo existencial, nessa medida, distingue-se do mero mínimo vital (SARLET; FIGUEIREDO, 2010, p. 22). ${ }^{15}$

De outra parte, sublinhe-se que o direito ao mínimo existencial também não coincide integralmente com o conteúdo do direito à vida, que é dotado de extensão muito maior. Para que a vida seja garantida é necessário, pelo menos, assegurar o mínimo existencial. Mas ele, por si só, não importa promoção do direito à vida em sua plenitude (TORRES, 2009, p. 37).

O mesmo se diga em relação ao princípio da dignidade humana: o seu conteúdo não se esgota no mínimo existencial. Para concretizar a dignidade da pessoa humana em sua máxima potencialidade, é necessário o respeito, a

\footnotetext{
${ }^{14}$ Jorge Reis Novais diferencia os autores que restringem o mínimo existencial a um mínimo vital ou fisiológico, de outros que nele englobam o mínimo sócio-cultural. Cf.: NOVAIS, 2010, p. 195.

${ }^{15} \mathrm{Na}$ mesma esteira, José Carlos Francisco entende que o mínimo existencial não engloba apenas o vital, fisiológico, "pois a concretização da dignidade humana impõe que essa existência seja em padrões dignos viabilizados por meios que assegurem a realização da natureza humana e a convivência social" (FRANCISCO, 2008, p. 859).
} 
proteção e a promoção dos direitos fundamentais através de um amplo conjunto de abstenções e ações estatais positivas, tais como: (i) criação de normas que coíbam a atuação de terceiros que violem a dignidade, como as normas penas que sancionam ofensas às liberdades, ou as normas trabalhistas que impedem a exploração da força de trabalho que atente contra a dignidade humana; (ii) a vedação de penas cruéis e degradantes pelo próprio Estado; (iii) a criação de mecanismos de participação popular nas tomadas de decisão política; entre outros. Logo, a proteção da dignidade humana não se dá apenas através do direito ao mínimo existencial, mas ele consiste em um dos instrumentos para assegurar, pelo menos, o núcleo essencial da dignidade (BITTENCOURT NETO, 2010, p. 117-118).

Quanto aos fundamentos jurídicos sobre os quais se assenta o direito em apreço, há consenso generalizado no sentido de que ele independe de expressa previsão constitucional ou legal (TORRES, 2009, p. 27). ${ }^{16}$ Cuida-se de direito fundamental implícito no tecido constitucional, derivado, segundo a maior parte dos autores, do princípio da dignidade da pessoa humana (CLÈVE, 2011, p. 106). ${ }^{17}$ Costuma-se referir, também, ao direito à vida (SARLET; FIGUEIREDO, 2010, p. 25), aos princípios da igualdade material e da solidariedade social (BITTENCOURT NETO, 2010, p. 103-113), à cláusula do Estado Social (LEIVAS, 2006, p. 133), aos objetivos fundamentais da República Federativa do Brasil, tal como a erradicação da pobreza e a redução das desigualdades regionais e sociais, e aos direitos de liberdade (eis que, sem condições materiais de existência, as liberdades fundamentais não podem ser exercidas) (TORRES, 2009, p. 8; 140-143). No ordenamento constitucional brasileiro há uma cláusula de abertura material do catálogo de direitos fundamentais, inserta no art. $5^{\circ}, \S 2^{\circ}$ da CF, segundo a qual: "Os direitos e garantias expressos nesta Constituição não excluem outros decorrentes do regime e dos princípios por ela adotados, ou dos tratados internacionais em que a República Federativa do Brasil seja parte". Admite-se, pois, a existência de direitos materialmente fundamentais, em virtude da proximidade do seu

\footnotetext{
${ }^{16}$ No mesmo sentido: SARLET; FIGUEIREDO, 2010, p. 25 e BITTENCOURT NETO, 2010, p. 121.

${ }_{17}$ Compartilham dessa posição: BARCELLOS, 2011, p. 243 et seq; SARLET, 2010, p. 320; TORRES, 2009, p. 149-153; BITTENCOURT NETO, 2010, p. 99-103.
} 
conteúdo com a essência da Constituição e dos demais direitos formalmente fundamentais, previstos no rol formalizado no Título II da Lei Maior. ${ }^{18}$ Portanto, não há maiores dificuldades em se reconhecer o direito ao mínimo existencial como direito fundamental, dada a sua evidente relação com os princípios constitucionais acima mencionados e com o regime democrático adotado pela Lei Fundamental de 1988.

\section{CONTEÚDO DO MÍNIMO EXISTENCIAL, RELAÇÃO COM DIREITOS FUNDAMENTAIS ECONÔMICOS E SOCIAIS E UTILIZAÇÃO COMO CRITÉRIO DE JUSTICIABILIDADE}

No que tange ao conteúdo do direito fundamental ao mínimo existencial, há também consenso doutrinário quanto a sua variabilidade no tempo e no espaço. Entende-se, desse modo, que as condições necessárias para garantir uma existência minimamente digna não são idênticas em todos os países e em todos os momentos históricos, devendo-se levar em consideração, para identificá-las, os padrões e o desenvolvimento econômico, social e cultural da sociedade que estiver em questão (LEAL, 2009, p. 93). ${ }^{19}$

Há, no entanto, um ponto de divergência no tocante ao conteúdo do mínimo existencial. Ainda que se admita, em geral, a sua variabilidade no tempo (modifica-se conforme a época em análise) e no espaço (transforma-se de acordo com o país em apreço), há pelo menos duas correntes distintas quanto à fixação desse conteúdo: aquela que aqui se denominará de conteúdo determinável no caso concreto, para a qual o mínimo existencial carece de conteúdo específico, e seus contornos só podem ser delimitados no caso concreto, diante das circunstâncias fáticas e das necessidades da pessoa sob exame; e aquela que será apelidada de rol constitucional preferencial, segundo a qual, embora varie conforme os momentos históricos e os diferentes Estados, o conteúdo do mínimo existencial pode ser definido a partir de um elenco preferencial, aprioristicamente fixado com base em elementos extraídos de

\footnotetext{
${ }^{18}$ Sobre o reconhecimento de direitos materialmente fundamentais, ver, na literatura jurídica portuguesa, as lições de: ANDRADE, 2004, p. 75-97. No Direito brasileiro, o tema é extensamente explorado por: SARLET, 2010, p. 78-140 e SARLET, 2006, p. 98-109.

${ }^{19}$ Adotam tal posição: SARLET; FIGUEIREDO, 2010, p. 21; KRELL, 2002, p. 63; FRANCISCO, 2008, p. 860; BITTENCOURT NETO, 2010, p. 119.
} 
cada sistema constitucional positivo, em um contexto temporalmente determinado.

A vasta maioria dos autores expressa concordância com o primeiro entendimento: a delimitação da essência do mínimo existencial deve ser realizada em cada caso concreto, submetido à apreciação do Estado. Para rejeitar a fixação a priori de um conjunto de prestações materiais imprescindíveis para assegurar uma vida minimamente digna, a doutrina majoritária aponta para as díspares necessidades que cada indivíduo pode apresentar, mesmo dentro de um determinado país e em um momento histórico temporalmente definido. É o caso de Ricardo Lobo Torres (2009, p. 13), Ingo Wolfgang Sarlet e Mariana Filchtiner Figueiredo (2010, p. 26-27), Eurico Bittencourt Neto (2010, p. 121), José Carlos Francisco (2008, p. 860), Cláudia Honório (2009, p. 261-266) e Rogério Gesta Leal (2009, p. 93).

Consoante este último autor, o mínimo existencial ostenta uma natureza relacional em face do tempo e do espaço, variando o seu conteúdo, v.g., se comparadas as realidades dos países africanos com a da Suíça. $O$ mesmo ocorreria internamente em cada Estado, exemplificando com as variações entre as necessidades existentes no interior dos Estados do Maranhão e da Paraíba com a situação de Estados como o Rio Grande do Sul e Santa Catarina. O jurista acena para as dessemelhanças em termos de quantidade e natureza das prestações que cada indivíduo, nessas diferentes conjunturas, pode precisar para viver dignamente, e chega a incluir como fatores que influenciam nessa variabilidade os eventos provocados por causas fortuitas ou de força maior (v.g., desastres naturais), que, no seu entender, podem alterar radicalmente a especificidade do mínimo existencial para cada cidadão (LEAL, 2009, p. 93).

Os adeptos dessa corrente tentam, ao menos, sugerir indicativos mínimos extraídos da experiência e de textos normativos nacionais e internacionais, que serviriam como parâmetros para a averiguação das condições materiais de existência digna em cada situação concreta. Andreas J. Krell entende que, conquanto variem os contornos concretos do mínimo existencial, nele está incluindo "sempre um atendimento básico e eficiente de saúde, o acesso a uma alimentação básica e vestimentas, à educação de 
primeiro grau e a garantia de uma moradia" (2002, p. 63). Ingo Wolfgang Sarlet, por sua vez, mencionando um conteúdo de caráter ilustrativo, refere-se à saúde, educação, moradia, assistência e previdência social, aos aspectos essenciais do direito ao trabalho e da proteção do trabalhador, à alimentação, ao fornecimento de serviços existenciais básicos como água, saneamento básico, transporte, energia elétrica, e o direito a uma renda mínima (2010, p. 321).

Extraindo esses indicativos do texto constitucional brasileiro, Eurico Bittencourt Neto toma como um dos exemplos de parâmetro o art. $7^{\circ}$, IV, da Constituição Federal, que assegura ao trabalhador brasileiro um "salário mínimo (...) capaz de atender a suas necessidades vitais básicas e às de sua família com moradia, alimentação, educação, saúde, lazer, vestuário, higiene, transporte e previdência social". A partir dessa norma, reputa que na sociedade brasileira atual será indispensável para existir dignamente a garantia de "alimentação, moradia, ensino fundamental, saúde básica, vestuário, além do acesso à Justiça, direito instrumental indispensável à eficácia dos direitos fundamentais" (2010, p. 121-122). Com apoio nesses parâmetros, entende que devem ser avaliadas, caso a caso, as necessidades específicas do indivíduo e o nível de satisfação exigível para se considerar respeitada a sua dignidade.

Víctor Abramovich e Christian Courtis colhem de normas internacionais protetivas de direitos humanos os elementos indicativos de uma vida humana minimamente digna. Explicam os autores que o Comitê de Direitos Econômicos, Sociais e Culturais das Nações Unidas reconhece a obrigação dos Estados de garantir níveis essenciais dos direitos econômicos e sociais. Cuida-se de uma "obrigação mínima dos Estados de garantir pelo menos níveis essenciais de cada um dos direitos", a qual retrata um ponto de partida no caminho voltado à plena efetividade desses direitos. O Comitê tentou definir o conteúdo básico de alguns dos direitos previstos pelo Pacto Internacional dos Direitos Econômicos, Sociais e Culturais ${ }^{20}{ }^{21}$ Em matéria de direito à saúde,

${ }^{20}$ O referido pacto foi adotado pela Resolução no 2.200-A (XXI) da Assembleia Geral das Nações Unidas, em 16 de dezembro de 1966 e ratificado pelo Brasil em 24 de janeiro de 1992. Sobre a tutela internacional dos direitos humanos econômicos, sociais e culturais, conferir: PIOVESAN, 2003, p. 233-262. e MELLO, 2003, p. 215-232. 
estaria compreendida a atenção primária básica da saúde, que englobaria: (i) acesso aos centros, bens e serviços de saúde, sem qualquer tipo de discriminação negativa, notadamente aos mais carentes; (ii) acesso a uma alimentação essencial mínima que seja nutritiva, adequada, segura e que assegure que ninguém morrerá de fome; (iii) acesso a um lar, uma moradia e condições sanitárias básicas, bem como fornecimento de água limpa potável; (iv) facilitação de medicamentos essenciais, em conformidade com as determinações periódicas do Programa de Ação sobre Medicamentos Essenciais da Organização Mundial da Saúde; (v) distribuição equitativa de todas as instalações, bens e serviços de saúde; entre outros. Em matéria de direito à educação, a obrigação mínima envolveria: (i) o direito de acesso as instituições e programas de educação pública sem qualquer discriminação; (ii) proporcionar educação primária a todos, com acesso universal; (iii) adotar e aplicar uma estratégia nacional de educação que compreenda educação secundária, superior e fundamental; (iv) velar pela livre escolha da educação sem a interferência do Estado ou de terceiros (ABRAMOVICH; COURTIS, 2004, p. 89-90).

Em que pese a adesão majoritária a esse raciocínio, considera-se, aqui, não ser essa a melhor solução para a problemática em tela. É que, embora seja certo que há mutações espaciais e temporais quanto às condições imprescindíveis para se viver dignamente, aceitar um conceito completamente aberto de mínimo existencial (ainda que calcado nos parâmetros mínimos acima oferecidos), suscetível a variações indiscriminadas da sua especificação ao sabor do intérprete, a depender do caso concreto, prejudica a funcionalidade operacional do instituto. Parece ser necessário extrair da sistemática constitucional de cada Estado, em um momento histórico determinado, o conjunto de elementos que se reputa essencial para assegurar uma vida minimamente digna a todos os cidadãos, independentemente das agruras e mazelas eventuais que possam acometer a apenas uma parcela de indivíduos. Explica-se.

\footnotetext{
${ }^{21}$ Buscando também em disposições internacionais o conteúdo do mínimo existencial, particularmente no art. 11 do Pacto Internacional dos Direitos Econômicos, Sociais e Culturais e no art. 25 da Declaração Universal dos Direitos Humanos: SAGGESE, 2009, p. 91-92.
} 
Retome-se o posicionamento de Rogério Gesta Leal, antes reproduzido. Baseando-se na necessidade que cada indivíduo pode apresentar para sua sobrevivência, entende o jurista que um interesse ou uma carência será "fundamental em nível de mínimo existencial quando sua violação ou nãosatisfação significa ou a morte, ou sofrimento grave, ou toca o núcleo essencial da autonomia" (2009, p. 103). Essa noção, além de demasiadamente aberta, parece ser exageradamente ampliativa, desbordando daquilo que se deve entender como mínimo existencial e prejudicando a funcionalidade dessa categoria como critério de definição das prestações materiais que não podem ser negadas pelo Poder Judiciário. Conforme observa Ana Paula de Barcellos, "se o critério para definir o que é exigível do Estado em matéria de prestações de saúde for a necessidade de evitar a morte, a dor ou o sofrimento físico, simplesmente não será possível definir coisa alguma", uma vez que quase toda prestação de saúde é capaz de encaixar-se nessa definição, dado que "é exatamente para tentar evitar a morte, a dor ou o sofrimento que elas foram desenvolvidas" (2008, p. 803-804). A noção de mínimo existencial deve ser mais restrita e bem delimitada, para impedir que toda e qualquer prestação estatal voltada à satisfação de um direito social possa nele se ver incluída.

A adoção de um critério tão vago e ampliativo conduz ao posicionamento que rejeita a possibilidade de se exigir judicialmente toda e qualquer prestação vinculada ao mínimo existencial, o que resulta num retrocesso justamente em relação àquilo que a formulação desse conceito pretendia avançar: formar uma categoria jurídica capaz de potencializar a exigibilidade imediata da parcela dos direitos econômicos e sociais essencial à garantia de uma vida minimamente digna, afastando com isso a lógica de refutação generalizada da justiciabilidade dos direitos sociais e de negação da sua jusfundamentalidade.

Note-se que o autor supracitado, apoiando-se no conceito alargado acima exposto, aduz que deve ser relativizada a ideia segundo a qual "uma violação do mínimo existencial (mesmo em se cuidando do núcleo existencial legislativamente concretizado dos direitos sociais) significará sempre uma violação da dignidade da pessoa humana e por esta razão será sempre desproporcional e, portanto, inconstitucional'. Aceita, dessa forma, que mesmo 
em se tratando de prestações relacionadas ao mínimo existencial, o desequilíbrio entre a infinidade de demandas existentes e a finitude dos recursos para satisfazê-las poderá levar "ao não atendimento integral e absoluto de direito fundamental individual ou social, exatamente para não violar de forma mais impactante direitos coletivos e difusos contrastantes" (LEAL, 2009, p. 104). O jurista exemplifica, então, com casos extremos por ele apreciados na via jurisdicional, que envolvem o direito à saúde, considerando, ao que tudo indica, que embora se tratasse de direito necessário à satisfação do mínimo existencial (porque imprescindível à sobrevivência do jurisdicionado), a sua concessão foi negada. ${ }^{22}$ Todavia, nos casos citados, parece que, diferentemente do que considerou o autor, não se tratavam de direitos incluídos no mínimo existencial.

Os critérios da sobrevivência e da atenuação do sofrimento do indivíduo, embora relacionados com a categoria em discussão, não são definitivos para inserir determinada prestação entre aquelas situadas na esfera do mínimo existencial. Isso porque, repise-se, colhendo-se o exemplo do direito à saúde, praticamente todos os tratamentos e medicamentos são criados para evitar a morte e eliminar a dor experimentada pelo cidadão. Por esse motivo, impende salientar que admitir a existência de um direito fundamental ao mínimo existencial não significa aceitar a ideia de que o Estado deve manter todos os cidadãos vivos o tempo todo, protegendo cada um, singularmente, contra toda e qualquer intempérie da vida, especialmente pela via judicial.

É precisamente em face dessa problemática que outros autores filiados à corrente aqui batizada de rol constitucional preferencial - sem deixar de reconhecer a mutabilidade do mínimo existencial no tempo e do espaço, consideram que o seu conteúdo pode ser previamente tracejado a partir de um elenco preferencial (ainda que não completamente infenso a mudanças),

\footnotetext{
${ }^{22}$ Entre os exemplos invocados pelo autor, está o de um postulante que requeria a concessão gratuita de medicamento para artrite reumatóide, com custo de $R \$ 10.200,00$ por mês. O quadro clínico não demonstrava gravidade e perigo de vida, nem a imprescindibilidade daquele medicamento para o tratamento (BRASIL. Tribunal de Justiça do Estado do Rio Grande de Sul. Agravo de Instrumento no 70013407242, 3aㅡ Câmara Cível, Rel. Des. Rogério Gesta Leal, julgado em 12.01.2006). Refere-se também ao caso de um requerente que pleiteava remédio especial para hepatite crônica, com custo aproximado de $R \$ 55.000,00$, o que representava $1300 \%$ a mais do que o valor do remédio convencional (BRASIL. Tribunal de Justiça do Estado do Rio Grande de Sul. Agravo de Instrumento no 70013844980, 3a Câmara Cível, Rel. Des. Rogério Gesta Leal, julgado em 16.03.2006). Cf.: LEAL, 2009, p. 104.
} 
extraído da ordem de prioridades definida pelas decisões político-jurídicas fundamentais do constituinte de cada Estado, em um momento histórico delimitado. Ou seja: julgam que as condições mínimas de existência digna não são totalmente variáveis e integralmente dependentes das necessidades de cada cidadão em sua situação concreta e singular, abarcando toda e qualquer prestação exigível para mantê-lo vivo e protegido contra qualquer sofrimento. Partem das priorizações emanadas de cada Constituição, para definir o conjunto de prestações básicas que deve ser assegurado a todos os indivíduos, indistintamente, permitindo-lhes viver de modo minimamente digno e desenvolver livremente a sua personalidade. Trata-se da segunda corrente de pensamento no que concerne à determinação do conteúdo do mínimo existencial, referida no início deste tópico. Parece ser essa a melhor resposta para a temática em epígrafe.

Tal posição encontra sua principal formulação na original proposta desenvolvida por Ana Paula de Barcellos. A construção dogmática dos contornos do mínimo existencial elaborada pela autora traduz-se na identificação dos dispositivos constitucionais que afetam diretamente o núcleo material da dignidade da pessoa humana. Destaque-se, desde já, que a jurista sublinha que a sua proposição quanto ao conteúdo do mínimo existencial veicula um parâmetro preferencial e não absoluto, que deve ser rediscutido em função de transformações fáticas e jurídicas. E não se trata de uma escolha aleatória, pois funda-se no texto constitucional (2011, p. 300-302).

As disposições constitucionais da Lei Fundamental de 1988 consistentes no mínimo existencial são reunidas sistematicamente por Ana Paula de Barcellos em quatro grupos, três de natureza material e um de caráter instrumental: a educação básica, a saúde básica, a assistência aos desamparados e o acesso à Justiça. Sua explicação assenta-se em um raciocínio lógico. A saúde e a educação ensejam um primeiro momento da dignidade humana, garantindo condições iniciais para que o indivíduo possa desenvolver sua personalidade de forma autônoma. Ademais, a educação configura um pressuposto para a participação do cidadão no Estado e para o exercício da cidadania. A assistência aos desamparados, prestada concomitantemente com os outros dois, tem por escopo evitar a indignidade 
absoluta, proporcionando condições materiais essenciais ao indivíduo, tais como vestuário, alimentação e abrigo, caso ele não possa assegurá-las por si mesmo. $O$ acesso à justiça, finalmente, revela-se como instrumento fundamental para proporcionar a garantia dos outros três, quando deixarem de ser observados pelo Estado (2011, p. 302-303). O importante, em suas lições, é compreender em que extensão cada um desses direitos encontra-se protegido pelo mínimo existencial.

Quanto à educação, o mínimo existencial engloba apenas as prestações referentes à chamada "educação básica", compreendida pela Constituição como obrigatória e gratuita, nos termos do art. 208, I, com a redação conferida pela Emenda Constitucional ํo 59/2009. ${ }^{23}$ Essa "educação básica", cujo acesso gratuito deve ser proporcionado pelo Poder Público por imposição constitucional, engloba, de acordo com o art. 21, I da Lei de Diretrizes e Bases da Educação (Lei no 9.394/1996), a educação infantil ${ }^{24}$, o ensino fundamental ${ }^{25}$ e o ensino médio ${ }^{26}$. O acesso à educação superior encontra-se fora da proteção do mínimo existencial, embora esteja englobado no direito fundamental social à educação, quando considerado em sua plenitude. Relembre-se que não se está tratando aqui das condições ideais do desenvolvimento humano, mas sim das condições para uma vida minimamente digna, que não requerem necessariamente altos níveis de escolaridade, embora seja desejável o seu alcance progressivo (BARCELLOS, 2011, p. 303308).

\footnotetext{
${ }^{23}$ Observe-se que na primeira edição de sua obra, Ana Paula de Barcellos afirmava que em matéria de educação, o mínimo existencial limitava-se à garantia de acesso gratuito ao "ensino fundamental", não englobando o "ensino médio". Isso porque, à época, o art. 208, I da Constituição estabelecia que o ensino gratuito e obrigatório restringia-se ao "ensino fundamental", não incluindo o ensino médio. Com a Emenda Constitucional $n^{\circ}$ 59/2009, foi alterada a redação do dispositivo, que passou a contemplar toda a "educação básica", que engloba a "educação infantil", o "ensino fundamental" e o "ensino médio", como obrigatória e gratuita. Como sua proposta é delineada com fulcro no texto constitucional, que reflete as prioridades políticas elegidas constituinte, a autora alterou a sua proposta, demonstrando, com isso, que a sua proposta de mínimo existencial não é absoluta e infensa às transformações fáticas e jurídicas de determinado Estado. Cf.: BARCELLOS, 2002, p. 262.

${ }^{24}$ Oferecida em creches ou entidades equivalentes, para crianças de até três anos de idade, e em pré-escolas, para as crianças de quatro a seis anos de idade (art. 30, I e II da Lei no 9.394/1996).

${ }^{25}$ Com duração de 9 anos, iniciando-se aos 6 anos de idade, voltado à formação básica do cidadão (art. 32, caput da Lei no 9.394/1996).

${ }^{26}$ Etapa final da "educação básica", com duração mínima de 3 anos (art. 35, caput da Lei no 9.394/1996).
} 
Assim, por integrar o conteúdo do mínimo existencial, o indivíduo poderá exigir judicialmente o acesso gratuito a uma vaga em escola pública, nos três níveis educacionais que integram a "educação básica". Constitui, segundo o $\S 1^{\circ}$ do art. 208 da CF, "direito público subjetivo", cujo não-oferecimento pelo Poder Público "importa responsabilidade da autoridade competente" (art. 208, $\S 2^{\circ}, \mathrm{CF}$ ). A inexistência de condições fáticas (recursos materiais e humanos) para oferecer as vagas faltantes autoriza o juiz a compelir o Estado a custear o ensino em uma escola privada, com padrão e custos similares, até que a Administração esteja em condições de prestar o serviço público adequadamente (BARCELLOS, 2011, p. 310). ${ }^{27}$

Em relação à saúde, exsurge flagrante dificuldade em delimitar quais prestações devem ser incluídas no mínimo existencial, visto que em um sem número de casos, a proteção da saúde do cidadão não comporta gradações. Sobre o assunto, questiona Barcellos: "O que seria o mínimo para o portador de leucemia em um estágio tal que a única prestação que the pode trazer alguma esperança é o transplante de medula?" (2011, p. 324). Os obstáculos se agravam quando se percebe que a maior parte das demandas judiciais de custeamento de tratamentos de saúde e de fornecimento de medicamentos não visa ao combate de situações e enfermidades que acometem as pessoas de baixa renda e que são suscetíveis de afetar a maior parte da população, tais como "hipertensão, diabetes, desnutrição, malária, doença de chagas, hepatite A, dengue, cólera, leptospirose, febre tifóide e paratifóide, esquistossomose, infecções intestinais ou ainda para atendimento cardiológico, oftalmológico ou ginecológico preventivo, pré e pós-natal" (BARCELLOS, 2008, p. 807).

Por isso, como dito linhas atrás, o mínimo existencial não pode abarcar toda e qualquer prestação de saúde que tenha o fito de evitar a dor, o sofrimento, ou mesmo a morte, porque isso implicaria aceitar a concessão judicial de financiamento de tratamentos caríssimos, destinados à cura de doenças raras, não para os representantes da camada pobre da população, mas sim para a classe média, dotada de informação sobre os seus direitos e sobre a forma de exercê-los, e munida de condições financeiras para

\footnotetext{
${ }^{27}$ No mesmo sentido: BARROSO, 2006, p. 146-147.
} 
reivindicá-los judicialmente. ${ }^{28}$ Prejudica-se, com isso, o financiamento de políticas públicas e serviços públicos de saúde universais, dirigidos à medicina preventiva e mesmo curativa de doenças que afetam a maior parte do povo brasileiro.

Assim como é penoso rejeitar uma demanda judicial de medicamento altamente custoso com fins curativos, tendo como consequência muitas vezes na morte do jurisdicionado, o "que dizer das milhares de mães que morrem no momento do parto porque os hospitais públicos dos três níveis federativos não as assistem? (...) Ou daquelas que morrem em decorrência de doenças relacionadas com a falta de saneamento (...)?" (BARCELLOS, 2008, p. 806). Em última análise, o único ponto distintivo entre o postulante da ação judicial e essas milhares de pessoas repousa sobre o fato de que essas últimas carecem de capacidade de mobilização. Aceitar, portanto, que o Poder Judiciário deve atender ao máximo do direito à saúde, inclusive em relação às prestações materiais que não estejam previstas na legislação ordinária, faz com que todos custeiem, mesmo que não tenham optado por isso no processo democrático travado no espaço de deliberação pública do Legislativo, as específicas necessidades de alguns poucos, que puderam recorrer à via judicial e lograram decisão favorável (BARCELLOS, 2011, p. 324).

Diante dos problemas apontados, Ana Paula de Barcellos pontua que a delimitação no mínimo existencial, na esfera ora analisada, deve restringir-se às prestações de saúde disponíveis a todos, afastando-se o critério nas melhores ou piores condições de saúde das pessoas para determinar o que deve e o que não deve ser concedido (2011, p. 325-326). Assim, as prestações relativas à saúde que fazem parte do mínimo existencial concernem apenas ao que a autora denomina de saúde básica. Nos demais casos será necessário que as opções políticas pertinentes à saúde assumam a forma de lei para que a sua realização possa ser pleiteada judicialmente (BARCELLOS, 2011, p. 322). ${ }^{29}$

\footnotetext{
${ }^{28}$ De acordo com Clèmerson Merlin Clève, "não pode (...) o cidadão pretender, num país como o nosso, exigir, no caso de padecer de determinada patologia, tratamento no exterior ou um tipo específico de tratamento apenas encontrável em distante rincão, ou uma forma de terapia absolutamente não recomendada pelos órgãos de saúde do país" (CLÈVE, 2011, p. 103).

${ }^{29} \mathrm{Na}$ visão da autora, se toda e qualquer prestação de saúde pudesse ser postulada perante o Judiciário, a autoridade pública se eximiria da obrigação de realizar as diretivas constitucionais
} 
O modelo proposto "propugna pela inclusão prioritária no mínimo existencial daquelas prestações de saúde": de que todos os indivíduos necessitaram (como o atendimento no parto e no pós-natal), necessitam (como o saneamento básico e o atendimento preventivo em clínicas especializadas, como cardiológica e ginecológica), ou provavelmente irão necessitar (como o acompanhamento e controle de doenças características da terceira idade, tal qual a hipertensão) ${ }^{30}$ (BARCELLOS, 2011, 328-329). Com isso, faz-se com que todos os indivíduos possam gozar de todas as ações possíveis e necessárias para prevenção e manutenção do seu estado de saúde. Dentro dessa lógica, assegura-se a todo e qualquer cidadão brasileiro o direito subjetivo a esse conjunto comum de prestações de saúde, podendo exigi-los imediatamente perante o Poder Judiciário caso ele não seja promovido de ofício pela Administração Pública. Além, é claro, de todas as demais prestações previstas em leis e atos administrativos ( $v$.g., fornecimento de medicamentos gratuitos de medicina curativa previstos em Portarias do Ministério da Saúde).

A assistência aos desamparados, por seu turno, é composta pelas pretensões que visam a impedir a indignidade em termos absolutos. Compreende os institutos já estabelecidos pela Constituição com essa finalidade ( $v$.g., "garantia de um salário mínimo de benefício mensal à pessoa portadora de deficiência e ao idoso que comprovem não possuir meios de prover à própria manutenção ou de tê-la provida por sua família" - art. 203, V), bem como a alimentação, o vestuário e o abrigo (BARCELLOS, 2011, p. 337). Ana Paula de Barcellos menciona três possíveis formas de prestação de assistência social: (i) pagamento de uma quantia em dinheiro ao necessitado ${ }^{31}$;

sob a escusa de aguardar as decisões judiciais, ou até sob a desculpa de que não há recursos para tanto, em função dos gastos com o cumprimento das decisões judiciais.

30 Conforme exposto pela constitucionalista, desta maneira são respeitadas as quatro prioridades estabelecidas pela Constituição: “(i) a prestação do serviço de saneamento (art. 23, IX, 198, II, e 200 IV); (ii) o atendimento materno-infantil (art. 227, I);(iii) as ações de medicina preventiva (art. 198, II); e (iv) as ações de prevenção epidemiológica (art. 200, II)". BARCELLOS, 2011, p. 329.

${ }^{31}$ Como é caso da Lei no 10.836/2004 (cria o Programa Bolsa-Família), que concede benefícios sociais aos desamparados, em proporções variáveis às necessidades de cada família: "Art. $2^{\circ}$. Constituem benefícios financeiros do Programa, observado o disposto em regulamento: I - o benefício básico, destinado a unidades familiares que se encontrem em situação de extrema pobreza; II - o benefício variável, destinado a unidades familiares que se encontrem em situação de pobreza e extrema pobreza e que tenham em sua composição gestantes, nutrizes, crianças entre 0 (zero) e 12 (doze) anos ou adolescentes até 15 (quinze) anos, sendo pago até o limite de 5 (cinco) benefícios por família; III - o benefício variável, vinculado ao adolescente, 
(ii) fornecimento de prestações assistenciais mediante o sistema de vales, à semelhança do que ocorre com o vale-alimentação e o vale-transporte; (iii) disponibilização dos bens - abrigo, alimentação e vestuário - in natura, em estabelecimentos mantidos pelo Poder Público (2011, p. 338-339). A autora apresenta, contudo, problemas intrínsecos a cada uma delas ${ }^{32}$. De acordo com o seu entendimento, seja qual for a forma escolhida para se prestar a assistência, deve-se possibilitar aos cidadãos ao menos exigir judicialmente os bens in natura, vale dizer, "o Estado deve dispor de um estabelecimento no qual as pessoas necessitadas possam se abrigar à noite, assim como de alguma forma de programa de alimentação e vestuário para esses indivíduos" (2011, p. 339).

O acesso à justiça, por fim, é o instrumento capaz de assegurar a postulação judicial dos direitos materiais componentes do mínimo existencial. Sua implementação, assim como a das demais prestações referidas, encontra obstáculos, como o custo ${ }^{33}$ e a desinformação, que impede o cidadão de ter conhecimento dos seus direitos materiais e da própria estrutura que the propiciaria 0 acesso à Justiça (BARCELLOS, 2011, p. 341-349). Consequentemente, o Ministério Público assume importante papel nesta empreitada, por meio da propositura de ações civis públicas que defendam valores vinculados a segmentos marginalizados na sociedade ${ }^{34}$, bem como a Defensoria Pública, no atendimento do direito fundamental à assistência jurídica gratuita, albergado pelo art. 5ㅇ, LXXIV da $\mathrm{CF}^{35}$.

Feitas essas considerações sobre as duas correntes acerca da delimitação do mínimo existencial - conteúdo determinável no caso concreto e rol constitucional preferencial - e manifestada a adesão à segunda pelas

destinado a unidades familiares que se encontrem em situação de pobreza ou extrema pobreza e que tenham em sua composição adolescentes com idade entre 16 (dezesseis) e 17 (dezessete) anos, sendo pago até o limite de 2 (dois) benefícios por família."

${ }^{32} \mathrm{Em}$ síntese, refira-se ao problema de o pagamento de um valor em pecúnia poder vir a desestimular o trabalho, bem como à dificuldade de implantação de um sistema de vales pelo Poder Judiciário por si próprio, enquanto ele não é criado pela via legislativa, uma vez que depende de decisões políticas e institucionais.

${ }^{33}$ Mais facilmente solucionável através da assistência judiciária gratuita, da institucionalização de Defensorias Públicas e da criação de Juizados Especiais Cíveis e Criminais.

${ }^{34}$ Tais como os desempregados (art. 170, VIII, da CF), os desprovidos de teto (art. 23, IX, da CF), os rurículas sem terra (art. 186 da CF), entre outros. MANCUSO, 2001, p. 794.

${ }^{35}$ Constituição da República Federativa do Brasil de 1988: "Art. 5०. (...) LXXIV - o Estado prestará assistência jurídica integral e gratuita aos que comprovarem insuficiência de recursos". 
razões já expendidas, cumpre traçar as linhas de separação entre o mínimo existencial e os direitos fundamentais sociais. Como visto, aquele não se confunde integralmente com estes. O direito fundamental ao mínimo existencial é composto por porções dos direitos econômicos e sociais necessárias a proporcionar ao seu titular condições materiais de existência minimamente digna. Ele é um minus em relação aos direitos sociais, os quais são providos de um conteúdo mais amplo, que engloba outros deveres - não só de prestação, mas também de abstenção - que ultrapassam a circunscrição do mínimo existencial. Os direitos econômicos e sociais, portanto, não têm por única e exclusiva função a satisfação do mínimo existencial (PULIDO, 2008, p. 149). ${ }^{36}$ Enquanto este último visa a "erradicar a pobreza e a marginalização", aqueles, em sua dimensão máxima, têm por objetivo a "redução das desigualdades sociais e regionais" e "garantir desenvolvimento nacional" na sua dimensão humana. ${ }^{37} \mathrm{O}$ mínimo existencial dirige-se ao combate da miséria ou pobreza absoluta, ao passo que os direitos econômicos e sociais destinamse à promoção da igualdade material entre os indivíduos (TORRES, 2009, p. 14-17).

O estabelecimento dessa diferenciação entre o conteúdo do mínimo existencial e os direitos sociais em sua integralidade tem se prestado à definição de um critério de justiciabilidade de condutas estatais positivas. Ocorre que, assim como a questão da definição de conteúdo do mínimo existencial, há também divergências em relação à utilização dessa categoria jurídica como critério de exigibilidade judicial das referidas prestações.

O ponto consensual nessa seara está na aceitação da possibilidade de se postular judicialmente condutas do Poder Público destinadas a suprir necessidades básicas e garantir condições mínimas de existência digna ao cidadão. ${ }^{38}$ Vale dizer: se a pretensão jurídica oposta ao Poder Judiciário tratar-

\footnotetext{
${ }^{36}$ Em sentido dimilar: SARLET; FIGUEIREDO, 2010, p. 25.

${ }^{37}$ Os termos entre aspas referem-se aos objetivos fundamentais da República Federativa do Brasil, previstos no art. 3oㅡ. II e III da Constituição Federal.

${ }^{38}$ Foi dito ponto de "consenso" e não "unanimidade" porque, da bibliografia consultada, a única posição aparentemente dissonante foi a de José Carlos Vieira de Andrade. O autor, em que pese reconheça sem qualquer reticência a existência do direito a condições mínimas de existência digna na Constituição Portuguesa, limita a sua aplicação imediata à dimensão negativa: ainda que não esteja legalmente regulamentado, esse direito pode ser invocado desde logo apenas para proibir a intervenção estatal no mínimo existencial, seja proibindo
} 
se da imposição de comportamentos estatais que integram o conjunto abarcado pelo mínimo existencial, o indivíduo poderá pleiteá-la. ${ }^{39}$ Derrubou-se com isso, no Direito brasileiro, a concepção segundo a qual todas as disposições constitucionais atinentes a direitos econômicos e sociais são normas programáticas, que não outorgariam ao cidadão um direito subjetivo sindicável judicialmente e limitar-se-iam a apontar fins a serem realizados progressivamente pelo Estado, dentro de sua esfera de discricionariedade. ${ }^{40}$

As divergências, por outro lado, centralizam-se em duas polêmicas. A primeira diz respeito à estrutura normativa do direito ao mínimo existencial (se princípio ou regra) e à sua forma de aplicação (se definitiva, em termos absolutos, ou se relativa, sujeita à ponderação). A segunda concerne à finalidade do mínimo existencial como critério de justiciabilidade de prestações positivas: para alguns, ele serve para definir apenas o mínimo exigível pela via

execuções (v.g., proibição da penhora para satisfação de créditos), seja vedando tributação sobre o rendimento necessário a uma vida minimamente digna. No entanto, parece não aceitar que o indivíduo possa exigir, positivamente, prestações estatais voltadas a propiciar condições materiais de existência com dignidade, enquanto não estiverem regulamentadas pela legislação. Cf.: ANDRADE, 2004, p. 404.

${ }_{39}$ Nessa linha: CLÈVE, 2011, p. 106-107; TORRES, 2009, p. 84 e 87-89; SARLET, 2010, p. 321-322 e 350-351; BARCELLOS, 2011, p. 243; SARMENTO, 2008, p. 578-579; LEAL, 2009, p. 100 e 103; AMARAL, 2001, p. 211-216; LEIVAS, 2006, p. 133; BITTENCOURT NETO, 2010, p. 130-131; MAURÍCIO JR., 2009, p. 76-77; HONÓRIO, 2009, p. 58 e 61.

${ }_{40}$ Nesse sentido, a seguinte decisão do Superior Tribunal de Justiça, que reputa as disposições constitucionais referentes ao direito à saúde como "normas constitucionais meramente programáticas": "Normas constitucionais meramente programáticas - ad exemplum, o direito à saúde - protegem um interesse geral, todavia, não conferem, aos beneficiários desse interesse, o poder de exigir sua satisfação - pela via do mandamus - eis que não delimitado o seu objeto, nem fixada a sua extensão, antes que o legislador exerça o munus de completá-las através da legislação integrativa. Essas normas (arts. 195, 196, 204 e 227 da CF) são de eficácia limitada, ou, em outras palavras, não tem força suficiente para desenvolver-se integralmente, 'ou não dispõem de eficácia plena', posto que dependem, para ter incidência sobre os interesses tutelados, de legislação complementar. Na regra jurídico-constitucional que dispõe 'todos tem direito e o estado o dever' - dever de saúde - como afiançam os constitucionalistas, 'na realidade todos não têm direito, porque a relação jurídica entre o cidadão e o Estado devedor não se fundamenta em vinculum juris gerador de obrigações, pelo que falta ao cidadão o direito subjetivo público, oponível ao Estado, de exigir em juízo, as prestações prometidas a que o Estado se obriga por proposição ineficaz dos constituintes"'. (BRASIL. Superior Tribunal de Justiça. Recurso Ordinário no Mandado de Segurança no 6.564/RS, Rel. Ministro Demócrito Reinaldo, Primeira Turma, julgado em 23.05.1996, DJ 17.06.1996). No mesmo influxo, a decisão do Tribunal de Justiça do Estado do Rio de Janeiro: "Mandado de segurança. Impetrantes portadores de insuficiencia renal crônica. Fornecimento de remédio (CELLCEPT) pelo Estado. As normas programáticas estabelecidas na Constituição Federal não conferem ao cidadão o direito subjetivo de exigir do Estado o fornecimento de remédios de alto-custo, em detrimento de outros doentes, igualmente carentes. Na consecução de sua obrigação de saúde pública a administração há que atender aos interesses mais imediatos da população. Impropriedade da via mandamental para atendimento do direito reclamado" (BRASIL. Tribunal de Justiça do Estado do Rio de Janeiro. Mandado de Segurança no 220/98, Rel. Del. Antonio Lindberg Montenegro, julgado em 17. 12.1998). 
judicial, devendo-se reconhecer a sindicabilidade de direitos sociais para além do seu campo de abrangência; para outros, ele se presta a determinar o máximo que se pode postular perante o Judiciário, devendo-se negar a concessão de prestações de direitos econômicos e sociais que o extrapolem.

Em relação ao primeiro foco de dissenso, ligado à estrutura normativa do mínimo existencial, há autores que Ihe imprimem a natureza de regra jurídica, aplicável consoante a lógica do "tudo ou nada" (corrente que se chamará de mínimo existencial definitivo), ao passo que outros the emprestam o caráter de princípio jurídico, entendendo que o seu comando impõe a sua realização na máxima medida possível, conforme as circunstâncias fáticas e jurídicas existentes (vertente que se denominará de mínimo existencial prima facie). ${ }^{41}$

Para o primeiro grupo, do mínimo existencial definitivo, ${ }^{42}$ a aplicação do mínimo existencial impõe-se à maneira das regras jurídicas, nos termos propostos por Ronald Dworkin, isto é, conforme a lógica do "tudo-ou-nada". ${ }^{43}$ Nesse sentido, por compor a noção de dignidade da pessoa humana de um modo tão fundamental, a exigibilidade do mínimo existencial não poderia ser afastada num embate com outros argumentos jurídico-normativos. Sua aplicação deve ser feita em termos absolutos, independentemente das circunstâncias fáticas e jurídicas do caso concreto. Desta sorte, quando postulado perante o Judiciário, mesmo diante de outras normas jurídicas que apontem no sentido contrário à concessão da demanda pleiteada - tais como o

\footnotetext{
${ }^{41}$ A distinção entre princípios e regras aqui referida baseia-se na adoção do critério da estrutura lógico-normativa, na esteira de Ronald Dworkin e Robert Alexy, uma vez que é essa a concepção compartilhada pela vastíssima maioria dos autores analisados que enfrentam 0 tema do mínimo existencial. Registre-se, no entanto, que há autores que distinguem os princípios das regras com base em outros critérios (tal como o do grau de fundamentalidade da norma), o que conduz a conclusões distintas. Para uma análise dos diferentes sentidos que a doutrina brasileira confere aos princípios jurídicos, ver: SILVA, 2003; CRUZ, 2006; e HACHEM, 2011, p. 136-144.

${ }^{42}$ Composto, entre outros, por: TORRES, 2009, p. 84 e 87-89; BARCELLOS, 2011, p. 243; BITTENCOURT NETO, 2010, p. 130-131; HONÓRIO, 2009, p. 58 e 61.

${ }^{43}$ Essa forma de aplicação das normas-regra, segundo Dworkin, funciona da seguinte maneira: se presente no mundo dos fatos a situação descrita na regra, de duas uma: ou a regra é válida, e aquilo que ela determina deve ser cumprido, ou ela é inválida, e, nesse caso, será irrelevante para a decisão. Havendo conflito entre duas regras, que descrevam a mesma situação fática e imponham ordens diversas, uma delas será inválida, de modo que o embate deverá ser resolvido pelos métodos previstos pelo próprio sistema jurídico para resolução de antinomias ( v.g., norma superior derroga a norma inferior, norma posterior derroga a norma anterior, norma especial derroga a norma geral). As regras possuem, portanto, apenas a dimensão de validade. DWORKIN, 2010, p. 39.
} 
princípio da separação de poderes, o princípio democrático, o princípio da legalidade orçamentária, e o argumento da reserva do possível - o mínimo existencial deverá prevalecer.

A corrente compreende o direito ao mínimo existencial como uma "exceção à clássica distribuição de funções em um Estado democrático", no qual o estabelecimento de prioridades e a tomada de decisões políticas acerca da distribuição de recursos compete primariamente à função legislativa. Ele se apresenta como o "trunfo principal" capaz de fazer ceder a legitimidade democrática das escolhas políticas do legislador, em favor da legitimidade constitucional da ação jurisdicional (BITTENCOURT NETO, 2010, p. 130). Sua incidência dá-se pelo método da subsunção, não podendo ser objeto de ponderação, uma vez que seu conteúdo coincide com o núcleo essencial irredutível dos direitos fundamentais, insuscetível de sopesamento (TORRES, 2009 , p. 84 e 87-89). Não se trata, na verdade, de efetiva blindagem contra qualquer ponderação: o que se entende é que esta já foi previamente realizada pelo constituinte - tornando-o, assim, um direito definitivo e não mais prima facie - ao erigir como fundamento da República Federativa do Brasil a dignidade da pessoa humana, de sorte que ao menos o seu núcleo essencial, exibido através do mínimo existencial, deve sempre ser tutelado.

Essa posição faz com que a categoria jurídica do mínimo existencial se torne extremamente útil e funcional como critério de justiciabilidade do conteúdo essencial dos direitos econômicos e sociais. Ela estabelece uma nítida linha demarcatória da extensão da legitimidade do Poder Judiciário para a efetivação desses direitos: estando dentro do âmbito de abrangência do mínimo existencial, a pretensão jurídica deve ser concedida pelo juiz, independentemente da reserva do financeiramente possível (TORRES, 2009, p. 53-54 e 105-106). ${ }^{44}$ Nessa toada, Cláudia Honório acentua a relevância do instituto para afastar as objeções utilizadas contra a efetivação dos direitos sociais, ao salientar que ele "reforça a proteção e realização dos direitos fundamentais, principalmente daqueles caracterizados pela sua dimensão

\footnotetext{
${ }^{44}$ A mesma opinião é defendida por: BITTENCOURT NETO, 2010, p. 98 e 131; HONÓRIO, 2009, p. 58.
} 
prestacional, contornando obstáculos colocados à efetivação dessas normas" (2009, p. 61).

Os adeptos da outra corrente - do mínimo existencial prima facie questionam como seria possível explicar, dentro dessa lógica, a ausência fática de recursos disponíveis nos cofres públicos para atender ao mínimo existencial de todos os cidadãos. Os defensores do mínimo existencial definitivo dão a resposta. Se é certo que em sociedades com baixo índice de desenvolvimento humano e econômico o atendimento ao mínimo existencial de todos os que necessitam poderia gerar uma situação de insuficiência de recursos capazes de fazer frente a todas as necessidades, tal fato não é capaz de obstar a natureza de regra do direito em apreço. É justamente nesses casos que se impõe uma proteção reforçada ao mínimo existencial. Se não há recursos suficientes sequer para assegurar as condições mínimas de existência digna da população de uma determinada sociedade, é porque houve eleição equivocada na ordem de prioridades de emprego dos recursos públicos, sendo, pois, fundamental conceder ao direito em referência uma proteção tal que o erija como prioridade máxima na promoção e manutenção dos meios imprescindíveis a uma existência digna, "em detrimento de outras escolhas feitas pelo legislador democrático" (BITTENCOURT NETO, 2010, p. 131).

É certo, também, que em matéria de prestações que integram o mínimo existencial, a determinação judicial pode implicar, dependendo do direito envolvido, não apenas custos financeiros como também, muitas vezes, a existência de normas organizatórias e procedimentais e de instituições públicas habilitadas a promover as ações judicialmente fixadas ( v.g., escolas, no caso do direito à educação; hospitais públicos, no caso do direito à saúde). Como, então, resolver a questão? Muito embora grande parte das normas referentes a direitos econômicos e sociais já estejam regulamentadas no plano infraconstitucional, a falta absoluta de aparatos institucionalizados necessários para a satisfação dos direitos ao mínimo existencial implicará a determinação de uso de serviços privados, às custas do Estado, até que ele disponha de meios materiais para tanto (BITTENCOURT NETO, 2010, p. 124).

Em sentido contrário, encontram-se os autores da vertente ora batizada de mínimo existencial prima facie, que enquadram o direito ao mínimo 
existencial na categoria normativa dos princípios jurídicos, compartindo, em sua maior parte, da construção de Robert Alexy sobre o tema. ${ }^{45}$ Entendem que esse direito, como os demais direitos fundamentais, decorre de norma jurídica prima facie (e não definitiva), que impõe a sua realização na máxima medida possível, de acordo com as circunstâncias fáticas e jurídicas do caso concreto. É possível que surjam argumentos contrários à satisfação das prestações atinentes ao mínimo existencial pela via judicial, tal como ocorre com os direitos sociais em geral. Os princípios acima referidos - separação de poderes, democrático, reserva legal orçamentária, reserva do possível, entre outros - podem ser invocados contra a sua realização, fazendo-o ceder no jogo de ponderação (SARLET, 2010, p. 321-322 e 350-351). ${ }^{46}$

Essa concepção compreende o mínimo existencial, sob o ponto de vista abstrato, como um direito prima facie, que pode ou não prevalecer, a depender do caso concreto. Ele só se tornaria um direito definitivo após a ponderação, pelo magistrado, com as demais normas envolvidas, que poderão, em uma dada situação, revestir-se de peso maior e afastá-lo. O resultado seria o indeferimento do pleito formulado pelo titular do direito. Aceitam, por conseguinte, que condições financeiras desfavoráveis possam ser arguidas para negar prestações voltadas à satisfação do mínimo existencial (LEIVAS, 2006, p. 133).

Tais autores situam o direito em questão na mesma seara dos demais direitos econômicos e sociais: a arena da ponderação. A diferença, no entanto, estaria no fato de que, por vincular-se ao núcleo essencial da dignidade da pessoa humana e dos direitos sociais em geral, o direito ao mínimo existencial

\footnotetext{
45 Consoante as lições de Robert Alexy, os princípios são normas que impõem ordens prima facie, isto é, determinam que algo seja realizado na maior medida possível, dentro das condições fáticas e jurídicas presentes no caso concreto. São, por isso, mandamentos de otimização, caracterizados por poderem ser aplicados em diferentes graus, a depender das circunstâncias de cada situação. A colisão entre princípios, de acordo com o autor, deve ser solucionada mediante a técnica da ponderação. Se dois princípios, num determinado caso, indicarem caminhos opostos a serem seguidos, não há que se declarar a invalidade de um deles, nem incluir uma cláusula de exceção. Um irá ceder passo ao outro, conforme o peso exercido por cada um deles naquelas circunstâncias. Através da ponderação se determinará qual princípio deve possuir um peso maior na situação específica, de sorte que o conteúdo de ambos os princípios colidentes seja realizado na maior medida possível, produzindo um resultado ótimo. Daí porque os princípios serem conceituados pelo autor como mandamentos de otimização. (ALEXY, 2007, p. 67-71).

${ }^{46}$ A corrente é também composta por: LEAL, 2009, p. 100 e 103; SARMENTO, 2008, p. 578579; AMARAL, 2001, p. 211-216; LEIVAS, 2006, p. 133; MAURÍCIO JR., 2009, p. 76-77.
} 
beneficia-se de um peso reforçado quando submetido ao sopesamento com princípios contrários, notavelmente maior do que aquele desfrutado pela parcela de direitos econômicos e sociais que excede esse mínimo. O ônus argumentativo para fazê-lo ceder, no caso concreto, será bem maior. Aí residiria o ponto distintivo entre o direito ao mínimo existencial e os direitos sociais em geral: aquele ostenta uma dimensão peso de maior do que estes frente a argumentos como a reserva do possível, mas todos eles estão sujeitos ao processo ponderativo (SARMENTO, 2008, p. 579).

Entre esses dois posicionamentos, assiste razão ao primeiro (mínimo existencial definitivo). Ainda que o direito ao mínimo existencial seja um direito fundamental como qualquer outro, e, se concebida a teoria dos direitos fundamentais como uma teoria dos princípios, tal qual o faz Robert Alexy, inexistem direitos absolutos, isso não significa que ele esteja na mesma condição dos direitos fundamentais sociais em geral e se sujeite à ponderação. ${ }^{47}$ Isso porque, em uma perspectiva mais atenta, ainda que se credite autonomia ao direito sob exame, o mínimo existencial já é o produto de uma ponderação operada previamente pelo constituinte, composto por um conjunto formado de parcelas de outros direitos fundamentais. Ele nasce justamente do resultado do processo ponderativo entre as diversas normasprincípio que impõem prima facie a realização maximizada dos direitos fundamentais sociais por elas veiculados. Diante do bloco de outros princípios, acima citados, que, também prima facie, restringem a realização otimizada desses direitos, opera-se um sopesamento para verificar quais fatias de cada um dos direitos fundamentais sociais em jogo sobrevive ao teste da proporcionalidade em suas três dimensões, ${ }^{48}$ para então chegar-se ao mínimo existencial, já como um direito definitivo.

O que ocorre, portanto, é uma verificação dos seguintes critérios: (i) adequação: quais medidas restritivas da potencialidade máxima dos direitos fundamentais sociais são adequadas para garantir o respeito aos princípios da

\footnotetext{
${ }^{47}$ Sobre a caracterização da teoria dos direitos fundamentais de Robert Alexy como uma teoria dos princípios, ver: ALEXY, 2007, p. 63-149.

${ }^{48}$ Consoante Clèmerson Merlin Clève e Alexandre Reis Siqueira Freire, é a partir da proporcionalidade "que se opera o 'sopesamento' (...) dos bens jurídicos quando se encontram em estado de contradição, oferecendo ao caso concreto solução ajustadora de coordenação e combinação dos bens em colisão". CLĖVE; FREIRE, 2003, p. 239.
} 
separação dos poderes, democrático, reserva legal orçamentária, entre outros; (ii) necessidade: quais limitações são efetivamente necessárias e menos restritivas do conteúdo dos direitos fundamentais sociais para garantir o resultado adequado; (iii) proporcionalidade em sentido estrito: quais são as prestações inerentes aos direitos fundamentais sociais que podem, dentro de um juízo de razoabilidade, ser exigidas do Estado. ${ }^{49}$ Tem-se, como fruto dessa prévia ponderação, após a aplicação do princípio da proporcionalidade em suas três vertentes, o direito definitivo ao mínimo existencial. ${ }^{50}$ Quando se chega no âmbito judicial, já não há mais espaço para se ponderar a esse respeito.

Some-se isso o fato de que, aceitando-se a debilidade desse direito fundamental por conta dos comumente evocados princípios da separação dos poderes e da legalidade orçamentária, bem como do argumento da reserva do financeiramente possível, não haverá verdadeira proteção reforçada do núcleo essencial da dignidade humana, capaz de justificar a criação de uma categoria jurídica distinta, tal como o mínimo existencial. Asseverar simplesmente que o seu afastamento no caso concreto faz recair um ônus maior sobre a argumentação judicial significa inquiná-lo de inutilidade. Torna-se nebulosa, se acolhida tal intelecção (mínimo existencial prima facie), a diferença, em termos práticos, entre o mínimo existencial e a parcela de direitos fundamentais sociais que o extrapolam. E mais obscura ainda se adotada a vertente - aqui já rejeitada - do conteúdo determinável no caso concreto, para a qual o conteúdo do mínimo existencial é totalmente aberto e variável e, ainda que calcado em indicativos e parâmetros mínimos, deve ser definido na situação concreta conforme as necessidades vitais e ocasionais do cidadão envolvido.

Caso abraçadas essas duas posições que foram aqui refutadas - de variabilidade total do mínimo existencial e de sujeição desse direito à ponderação - chega-se à seguinte conclusão: ninguém sabe, com precisão, o que é mínimo existencial, e a referência a ele, em termos de exigibilidade judicial, também não significa nada em concreto, pois cada juiz definirá as

\footnotetext{
${ }^{49}$ Sobre a aplicação do princípio da proporcionalidade através dos critérios de adequação, necessidade e proporcionalidade em sentido estrito no caso de colisão entre direitos fundamentais, ver: ALEXY, 2007, p. 91-95.

${ }_{50}$ Para uma análise intensamente aprofundada do princípio da proporcionalidade em matéria de direitos fundamentais, ver: PULIDO, 2003.
} 
prestações por ele abarcadas, de modo distinto em cada caso, e a certificação de que o pedido do autor está incluído nesse mínimo tampouco significa coisa alguma, visto que ele poderá ser rejeitado mesmo assim. Por conseguinte, essas duas compreensões não contribuem para a resolução do problema da sindicabilidade judicial dos direitos econômicos e sociais.

É preferível, pelos motivos até agora alinhavados, determinar o conteúdo do mínimo existencial a priori, traçando um elenco preferencial identificável a partir das prioridades fixadas no texto constitucional em um determinado momento histórico, que envolvam prestações necessárias a todos os cidadãos, e não apenas acidentalmente a alguns (rol constitucional preferencial), e enquadrá-lo na categoria normativa de regra, imprimindo-Ihe a natureza de direito definitivo, infenso à ponderação (mínimo existencial definitivo).

No que toca à segunda questão divergente quanto à utilização do conceito mínimo existencial em matéria de exigibilidade judicial de comportamentos estatais positivos, existe também, como dito, dois entendimentos, que serão aqui rotulados de mínimo existencial como teto máximo e de mínimo existencial como piso mínimo.

O primeiro deles, mais restritivo, emprega o mínimo existencial como teto máximo, vale dizer, como o critério que determina o ponto culminante da sindicabilidade da dimensão prestacional dos direitos fundamentais. Sendo imprescindíveis para uma existência minimamente digna, as prestações do Poder Público estarão incluídas no seu campo de abrangência, sendo prontamente postuláveis perante o Judiciário, independentemente de previsão legislativa. Porém, para além desse limite, que indicaria o ápice da exigibilidade judicial, as prestações atinentes a direitos econômicos e sociais estariam sujeitas à implementação progressiva pelo legislador, dependendo das escolhas políticas determinadas pelo processo democrático de deliberação pública. ${ }^{51}$

Em que pese nem todos os adeptos dessa corrente neguem a jusfundamentalidade dos direitos sociais no que extrapolam o mínimo

${ }^{51}$ São adeptos dessa posição: TORRES, 2009, p. 84 e 87-89; BARCELLOS, 2011, p. 292. 
existencial, ${ }^{52}$ ela está intimamente ligada com a posição capitaneada no Brasil por Ricardo Lobo Torres, de acordo com a qual os direitos sociais só são fundamentais em relação ao seu conteúdo essencial, necessário a garantir o mínimo existencial. Por se revestirem de jusfundamentalidade, essas parcelas

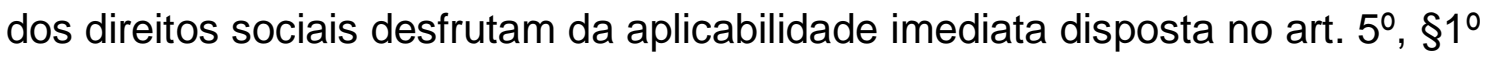
da Constituição Federal. A justificativa seria de que a atuação judicial excedente ao mínimo existencial ameaça a democracia e a ordem financeira, além de ter como efeito nefasto a apropriação particular de recursos públicos pelas classes mais abastadas, frente à incapacidade de informação e econômica dos mais pobres de conhecer os seus direitos, saber como exercitálos e dispor de meios para reivindicá-los pela via judicial. Haveria, pois, um prejuízo às políticas universais que atingem a população mais carente e necessitada (TORRES, 2009, p. 121-135).

O segundo posicionamento utiliza o mínimo existencial como piso mínimo, indicando-o como critério para definir aquilo que, sem dúvida, pode ser pleiteado perante os juízes em matéria de direitos fundamentais prestacionais sem maiores questionamentos. Isso não significa, porém, que o cidadão só possa requerer condutas positivas do Poder Público que se encontrem protegidas por esse mínimo: é possível pleitear a satisfação das parcelas dos direitos econômicos e sociais que desbordam do mínimo existencial, desde que, num processo ponderativo com os demais princípios constitucionais envolvidos, sua prevalência encontre-se justificada. ${ }^{53}$

Nessa senda, Ingo Wolfgang Sarlet esclarece, expressamente, que muito embora advogue a tese de que as prestações necessárias à garantia do mínimo existencial são judicialmente exigíveis, isso não afasta a possibilidade de se reconhecer a exigibilidade judicial de outros direitos a prestações dedutíveis diretamente da Constituição, que ultrapassem esse mínimo. Pontua, no entanto, que nessa seara, que supera os limites do mínimo existencial, haverá um espaço maior para ponderação diante dos argumentos que importam objeções à satisfação dos direitos sociais (SARLET, 2010, p. 350). Em sentido similar, sustenta Daniel Sarmento que a fronteira de intervenção do

\footnotetext{
${ }^{52}$ Como tem-se a impressão de ser o caso de Ana Paula de Barcellos.

53 É O caso dos seguintes autores: CLĖVE, 2011, p. 106-107; SARLET, 2010, p. 350; SARMENTO, 2008, p. 579; LEIVAS, 2006, p. 133; BITTENCOURT NETO, 2010, p. 144.
} 
Judiciário irá depender do sopesamento realizado em cada situação, figurando em uma das balanças o direito social vindicado e, na outra, "os princípios concorrentes, como a democracia, a separação de poderes e os direitos de terceiros que seriam atingidos ou economicamente inviabilizados caso fosse universalizada a prestação demandada" (SARMENTO, 2008, p. 579).

Independentemente da inexistência de qualquer lei disciplinadora dos direitos econômicos e sociais, é inquestionável a necessidade de inserir na esfera de aplicabilidade imediata o mínimo existencial, o qual se tornou o mínimo denominador comum da doutrina brasileira em matéria de justiciabilidade de direitos fundamentais sociais. As prestações estatais positivas destinadas à satisfação de direitos fundamentais sociais que integrem o mínimo existencial serão sempre exigíveis perante o Judiciário por meio de qualquer instrumento processual, de forma definitiva, e independentemente de regulamentação legislativa, previsão orçamentária, disponibilidade financeira ou existência de estrutura organizacional do Poder Público para atendê-las. Conforme os motivos já arrazoados, considera-se neste estudo preferível adotar a ideia de rol constitucional preferencial quanto à definição do conteúdo do mínimo existencial, não o deixando completamente aberto à determinação judicial no caso concreto. Entende-se, ademais, que ao mínimo existencial não podem ser opostos argumentos em contrário, sujeitando-o à ponderação, tal como se aceita quando se cuidam de prestações que excedem as condições mínimas de existência digna. Isso enfraquece $O$ instituto e the retira a funcionalidade. A inexistência de estrutura adequada e condições fáticas, por parte do Estado, para efetivá-lo, impõe a sua condenação ao custeamento de serviços privados equivalentes.

Uma vez que aqui se reconhece a jusfundamentalidade integral dos direitos econômicos e sociais, não a restringindo ao mínimo existencial, não parece ser possível acolher a tese do mínimo existencial como teto máximo. Ele deve ser considerado um piso mínimo, sendo aceitável a demanda judicial de parcelas de direitos fundamentais sociais que o extrapolem, desde que observada uma importantíssima ressalva: deve ser possível deduzir diretamente do texto constitucional os contornos das prestações que se pretende postular. Não se defende, por conseguinte, que qualquer pretensão 
vinculada a um direito fundamental social possa ser satisfeita pelo juiz, como se the competisse ponderar caso a caso acerca da razoabilidade do pedido. $O$ critério proposto para as parcelas de direitos fundamentais sociais que não estão incluídas no mínimo existencial é: se - e somente se - já houver normatização da Constituição a respeito, ainda que ultrapasse os limites do mínimo, essa prestação do direito fundamental social poderá ser requerida em face do juiz por gozar de aplicabilidade imediata, nota característica do regime jurídico dos direitos fundamentais.

Logo, tratando-se de prestações estatais positivas em matéria de direitos fundamentais sociais, ainda que inexistente lei regulamentadora, poderá ser postulado judicialmente o conteúdo especificado pelo texto constitucional, mesmo que desborde do mínimo existencial, e sem a necessidade de impetração de mandado de injunção. Isso porque, ainda que carentes de regulamentação legislativa, os direitos fundamentais sociais desfrutam de um conteúdo pré-estabelecido pelo constituinte. E como a posição aqui adotada credita jusfundamentalidade aos direitos econômicos e sociais para além do mínimo existencial, impõe-se a aceitação de justiciabilidade desses direitos não limitada ao conjunto de prestações que o compõem.

Essa compreensão do conteúdo jusfundamental dos direitos sociais dotado de aplicação imediata - para além do mínimo existencial não é tarefa difícil em Constituições como a brasileira, generosa em disposições regulamentadoras desses direitos. Ela adianta "na maior parte dos casos, normas organizatórias, deveres e posições ativas que decorrem das disposições jusfundamentais" (BITTENCOURT NETO, 2010, p. 146). No contexto pátrio atual, a Constituição encontra-se recheada de disposições normativas que disciplinam o conteúdo dos direitos fundamentais sociais. Conquanto os enuncie abstratamente no art. 6o - "São direitos sociais a educação, a saúde, a alimentação, o trabalho, a moradia, o lazer, a segurança, a previdência social, a proteção à maternidade e à infância, a assistência aos desamparados, na forma desta Constituição" - a Lei Fundamental de 1988 retoma a regulação jurídica dos direitos sociais no seu Título VIII - "Da Ordem Social". 
A saúde é tratada pelos arts. 196 a 200, e ganhou maior detalhamento

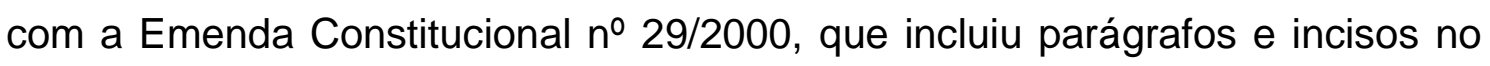
art. 198, vinculando receitas da União, dos Estados e dos Municípios para ações e serviços públicos de saúde. A educação é regulamentada pormenorizadamente dos arts. 205 a 214, contendo inclusive a concessão, já mencionada, de gratuidade do acesso à educação básica, que envolve a educação infantil, o ensino fundamental e o ensino médio, reconhecendo-a como direito público subjetivo do cidadão. Também há a previsão de vinculação de receitas públicas para atividades voltadas à educação, inserida pela Emenda Constitucional ㄲo 14/1996.

A especificação constitucional de conteúdos ocorre, igualmente, com os direitos à previdência social - arts. 201 e 202 e seus diversos parágrafos, que estabelecem, inclusive, os critérios para a garantia da aposentadoria no regime geral da previdência - e à assistência social (arts. 203 e 204, reconhecendo-se expressamente no inciso $V$ do primeiro a garantia de um salário mínimo de benefício mensal à pessoa portadora de deficiência e ao idoso que comprovem não possuir meios de prover à própria manutenção ou de tê-la provida por sua família).

Todas essas delimitações dos contornos dos direitos fundamentais sociais operadas diretamente pela Constituição podem ser reclamadas em juízo, ainda que não regulamentadas por lei e por mais que ultrapassem as prestações necessárias para garantir uma existência minimamente digna. É desnecessário, nesses casos, o mandado de injunção, ${ }^{54}$ porque se tratam de decisões políticas fundamentais empreendidas pelo constituinte, que sequer estão na esfera de disponibilidade do legislador ordinário. Logo, são também prontamente exigíveis.

A dimensão prestacional dos direitos fundamentais não disciplinados pela legislação só será plenamente justiciável pelos meios processuais comuns se for possível extrair diretamente da Constituição os traços que compõem o seu conteúdo, permitindo a identificação precisa das prestações específicas que ensejam direitos subjetivos a prestações materiais. Exemplifique-se com o direito dos idosos maiores de 65 anos à gratuidade do transporte coletivo

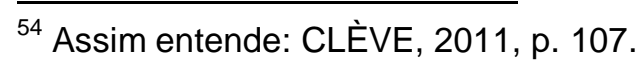




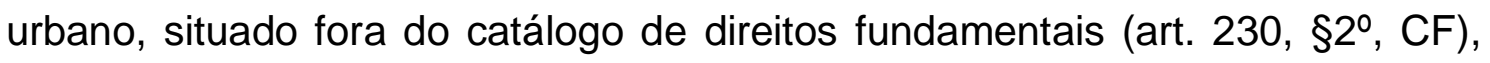
mas a ele reconduzível por meio da cláusula de abertura material do art. $5^{\circ}$, $\S^{2^{\circ}}$ da CF. Embora não se considere, aqui, que essa pretensão jurídica esteja incluída no mínimo existencial, ${ }^{55}$ julga-se possível reclamá-la jurisdicionalmente diante da sua violação. Não se cuida de disposição que exige lei ordinária para ser postulada.

Registre-se que essa intelecção aplica-se tanto aos deveres de promoção (prestações materiais do Estado) quanto aos deveres de proteção (contra atos de outros particulares) dos direitos fundamentais sociais. Os direitos dos trabalhadores enunciados nos arts. $7^{\circ}$, $8^{\circ}$ e $9^{\circ}$ da Constituição podem ser exigidos judicialmente, obrigando o Poder Público a protegê-los contra a ação dos empregadores, na medida em estejam bem especificados no texto constitucional, ainda que não haja lei regulamentadora. Por mais que a disposição veiculadora do direito o condicione à "forma da lei", como é o caso dos incisos I, IV, X, XI, XII, XIX, XX, XXI, XXII, XXIII, XXVII do art. 7ํa a previsão de um conteúdo mínimo do direito possibilita a sua reivindicação judicial. Ainda que inexistisse fixação legal do valor do salário mínimo (art. 7º, IV, CF), por exemplo, o dispositivo já estabelece pormenorizadamente aquilo que deve ser abrangido por esse valor (atendimento das necessidades vitais básicas do trabalhador e as de sua família com moradia, alimentação, educação, saúde, lazer, vestuário, higiene, transporte e previdência social), permitindo com isso a sua definição pelo juiz. ${ }^{56}$ Nas hipóteses em que não há esse conteúdo constitucional mínimo, sendo imprescindível a determinação infraconstitucional do conteúdo da prestação a ser exigida de outros particulares (v.g., participação do trabalhador nos lucros ou resultados da

\footnotetext{
${ }^{55}$ Conforme se verá a seguir, o Supremo Tribunal Federal, em decisão da qual se discorda, manifestou entendimento diverso. Apesar de aqui concordar-se com o entendimento de que essa prestação é sindicável judicialmente, discorda-se da conclusão da Ministra Cármen Lúcia Antunes Rocha quando entendeu que tal prestação estava incluída no mínimo existencial. Cf.: BRASIL. Supremo Tribunal Federal. Ação Direta de Inconstitucionalidade no 3768, Relatora Ministra Cármen Lúcia Antunes Rocha, Tribunal Pleno, julgado em 19.09.2007, DJe-131, divulgado em 25.10.2007, publicado em 26.10.2007.

${ }^{56}$ É o posicionamento de MELLO, 2010, p. 49-52. O autor vai além, sustentando ainda a possibilidade de revisão judicial do valor, caso esteja fixado em lei e não atenda $A$ todas as necessidades estabelecidas no art. $7^{\circ}$, IV da CF.
} 
empresa, conforme definido em lei - art. 7ํ, XI, CF), será necessária a propositura de mandado de injunção (art. $5^{\circ}$, LXXI, CF). ${ }^{57}$

Quanto aos deveres de promoção (prestações fáticas), nos casos que dependam de conformação legislativa do conteúdo da prestação o Judiciário não poderá tomar as decisões políticas e realizar as escolhas de prioridades no manejo dos recursos públicos, pois estas ficarão reservadas ao espaço de deliberação pública próprio do Poder Legislativo (BITTENCOURT NETO, 2010, p. 150). A não ser que já existam disposições infraconstitucionais disciplinando matéria análoga, o que autoriza, pela via específica do mandado de injunção, a viabilização judicial do exercício do direito fundamental. llustre-se com o direito dos servidores públicos a uma aposentadoria especial, com requisitos diferenciados para a sua concessão, nos casos de atividades de risco, prejudiciais à saúde e à integridade física, ou de portadores de deficiência (art. 40, $\S 4^{\circ}$, I, II, III da CF). ${ }^{58}$

\section{CONSIDERAÇÕES FINAIS: O MÍNIMO EXISTENCIAL E AS MANIFESTAÇÕES DA JURISPRUDÊNCIA BRASILEIRA}

Impende tecer breves apontamentos acerca das manifestações jurisprudenciais em solo nacional a propósito da temática vertente, apenas com o intuito de cotejar a acolhida do mínimo existencial pela doutrina

\footnotetext{
${ }^{57}$ De acordo com o citado dispositivo: "conceder-se-á mandado de injunção sempre que a falta de norma regulamentadora torne inviável o exercício dos direitos e liberdades constitucionais e das prerrogativas inerentes à nacionalidade, à soberania e à cidadania". Em outro trabalho, teve-se a oportunidade de sustentar que ante a impetração desse remédio constitucional, compete ao Poder Judiciário viabilizar o exercício do direito, podendo emprestar à decisão efeitos inter partes ou erga omnes, conforme as exigências concretas das situações de direito material em jogo. A regra geral é a atribuição de efeitos inter partes; contudo, sendo difusos ou coletivos os direitos em questão, pode-se conferir efeitos erga omnes à decisão. Nessa última hipótese, "a melhor solução parece ser a seguinte: (a) o juiz deverá, liminarmente, criar a solução adequada à satisfação do direito do titular no caso concreto; (b) sendo a solução criada satisfatória à tutela do direito, poderá a liminar concedida assumir caráter definitivo; (c) em havendo necessidade de elaboração de norma com alcance mais amplo do que a solução provida liminarmente, caberá ao juiz a utilização de todos os meios possíveis para ampliar o debate acerca da criação da norma, promovendo um diálogo constitucional entre todos os interessados, envolvendo os poderes estatais e a sociedade" (HACHEM, 2012, p. 180-181).

${ }^{58}$ Constituição da Republica Federativa do Brasil: "Art. 40. (...) § 4으 Eedada a adoção de requisitos e critérios diferenciados para a concessão de aposentadoria aos abrangidos pelo regime de que trata este artigo, ressalvados, nos termos definidos em leis complementares, os casos de servidores: I portadores de deficiência; II que exerçam atividades de risco; III cujas atividades sejam exercidas sob condições especiais que prejudiquem a saúde ou a integridade física".
} 
constitucionalista brasileira com a prática operada cotidianamente nos órgãos jurisdicionais pátrios.

Consoante já mencionado, operou-se verdadeira mudança na orientação judicial brasileira no que tange ao reconhecimento de eficácia jurídica e força normativa cogente às normas constitucionais veiculadoras de direitos econômicos e sociais. De decisões que Ihes rejeitavam a possibilidade de investir o cidadão de posições jurídico-subjetivas, capazes de serem demandadas judicialmente, passou-se a conceder - até mesmo de forma indiscriminada e não criteriosa - prestações estatais positivas, sobretudo em matéria de direito à saúde.

É o caso de julgados conhecidos do Supremo Tribunal Federal, que passaram a deferir pedidos de tratamentos de saúde de altíssimo custo, alguns deles no exterior e sem comprovação da eficácia dos seus resultados, destinados a cura de doenças raras, com lastro no art. 6º , que prevê a saúde como direito fundamental social, e no art. 196, que a define como "direito de todos e dever do Estado".

Um dos leading cases da matéria foi a decisão monocrática proferida pelo Ministro Celso de Mello na Medida Cautelar proposta na Petição no 1246 1. Tratava-se, no caso, de ação ajuizada contra o Estado de Santa Catarina, na qual um portador da doença rara Distrofia Muscular de Duchene - moléstia degenerativa de células musculares - asseverava existir tratamento em clínica estadunidense capaz de curá-lo. Supedaneado pelo art. 196 da Constituição, dentre outros, postulou a proteção de seu direito à saúde mediante o custeamento, pelo Poder Público, do aludido tratamento, que importaria o valor de US\$ 63 mil. A liminar foi concedida, e o Estado de Santa Catarina recorreu ao Tribunal de Justiça. A questão chegou ao STF, no momento em que o Estado-membro postulou à Corte a suspensão da tutela antecipada, sob o argumento de violação aos arts. 37, 100 e 167 da Constituição, por ter havido ordem de pagamento sem base no orçamento, nem em lei que o determinasse. Através de despacho singular, o Ministro negou a suspensão pleiteada, arguindo que: 
Entre proteger a inviolabilidade do direito à vida, que se qualifica como direito subjetivo inalienável assegurado pela própria Constituição da República (art. 5ํㅡ, caput) ou fazer prevalecer, contra esta prerrogativa fundamental, um interesse financeiro e secundário do Estado, entendo - uma vez configurado este dilema - que as razões de índole ética-jurídica impõem ao julgador uma só e possível opção: 0 respeito indeclinável à vida. ${ }^{59}$

Essa passagem tornou-se paradigma para decisões proferidas posteriormente em matéria de direito à saúde, tendo sido reproduzida no Recurso Extraordinário ํo 267.612, no Agravo de Instrumento oㅜ 570.445, no Agravo Regimental no Recurso Extraordinário o 271.286, no Recurso Extraordinário no 198.265, no Recurso Extraordinário oㅜ 248.304, no Agravo Regimental no Recurso Extraordinário no 273.834 e no Recurso Extraordinário no $393.175 .{ }^{60}$ Posição semelhante foi adotada na decisão monocrática proferida no Recurso Extraordinário no 342.413, pela Ministra Ellen Gracie, na qual restou consignado que "obstáculo de ordem burocrática ou orçamentária (...) não podem ser entraves ao cumprimento constitucional que garante o direito à vida" ${ }^{11}$, bem como no voto do Ministro Sydney Sanches no Recurso Extraordinário n 198.263 , no qual afirmou que "em matéria tão relevante como a saúde, descabem disputas menores sobre legislação, muito menos sobre verbas, questão de prioridade" 62 .

Embora bem intencionadas, decisões dessa natureza deixam de levar em conta aspectos essenciais da satisfação universal dos direitos fundamentais sociais, que, como visto, não devem ser efetivados apenas individualmente e pela via judicial, comprometendo os recursos de políticas públicas e serviços públicos para o atendimento dos poucos que tiveram condições de requerê-los perante o Judiciário (CLĖVE, 2011, p. 103). Esse primeiro impulso do Supremo Tribunal Federal, portanto, não empregava o mínimo existencial como um critério para a realização jurisdicional de direitos fundamentais sociais.

\footnotetext{
${ }^{59}$ BRASIL. Supremo Tribunal Federal. Medida Cautelar na Petição no 1246, Presidente Ministro Sepúlveda Pertence, Decisão Proferida pelo Ministro Celso de Mello, julgado em 31.01.1997, publicado em DJ 13.02.1997.

${ }^{60}$ Conforme dá notícia WANG, 2010, p. 354, nota oo 19.

${ }^{61}$ BRASIL. Supremo Tribunal Federal. Recurso Extraordinário no 342.413, Relatora Ministra Ellen Gracie, julgado em 14.10.2004, publicado em DJ 09.11.2004.

${ }_{62}$ BRASIL. Supremo Tribunal Federal. Recurso Extraordinário oㅜ 198.263, Relator Ministro Sydney Sanches, julgado em 12.02.2001, publicado em DJ 30.03.2001.
} 
Outros julgados, posteriormente, passaram a levar em conta a reserva do possível e as limitações orçamentárias como óbices à plena satisfação dos direitos sociais em sede judicial. ${ }^{63}$ Segundo Daniel Wei Liang Wang, essa mudança da posição majoritária da Corte em matéria de saúde ocorreu a partir do ano de 2007 (2010, p. 356-359). Mas ainda assim, embora tais decisões abordem a temática geral dos direitos sociais, a maior parte dos julgados que se refere especificamente ao conceito de mínimo existencial limita-se a fazer alusão a essa categoria apenas de forma pontual e sem muita precisão teórica. $^{64}$

Uma das mais expressivas e mencionadas decisões da Corte, conquanto prolatada mais em caráter doutrinário do que propriamente jurisprudencial, eis que houve perda do objeto da demanda, foi aquela exarada pelo Ministro Celso de Mello na Arguição de Descumprimento de Preceito Fundamental o 45 . No decisum, o Relator admite a reserva do possível como cláusula impeditiva da exigibilidade judicial do conteúdo integral dos direitos sociais, consignando que a sua realização "depende, em grande medida, de um inescapável vínculo financeiro subordinado às possibilidades orçamentárias do Estado, de tal modo que, comprovada, objetivamente, a incapacidade econômico-financeira da pessoa estatal, desta não se poderá razoavelmente exigir, considerada a limitação material referida, a imediata efetivação do comando fundado no texto da Carta Política". Por outro lado, o Ministro atesta expressamente a impossibilidade de o Estado invocar tal argumento para

\footnotetext{
${ }^{63}$ Citem-se, como exemplos, as decisões da Ministra Ellen Gracie na Suspensão de Tutela Antecipada no 91 e da Suspensão de Segurança no 3073, nas quais a Ministra leva em conta a limitação de recursos públicos e a necessidade de alocá-los de forma racional para atingir um maior número de cidadãos, posicionando-se da seguinte forma: "Entendo que a norma do art. 196 da Constituição da República, que assegura o direito à saúde, refere-se, em princípio, à efetivação de políticas públicas que alcancem a população como um todo, assegurando-lhe acesso universal e igualitário, e não a situações individualizadas. A responsabilidade do Estado em fornecer os recursos necessários à reabilitação da saúde de seus cidadãos não pode vir a inviabilizar o sistema público de saúde. No presente caso, ao se conceder os efeitos da antecipação da tutela para determinar que o Estado forneça os medicamentos relacionados '(...) e outros medicamentos necessários para o tratamento (...)' (fl. 26) dos associados, está-se diminuindo a possibilidade de serem oferecidos serviços de saúde básicos ao restante da coletividade". Cf.: BRASIL. Supremo Tribunal Federal. Suspensão de Tutela Antecipada no 91, Relatora Ministra Presidente, Decisão Proferida pela Ministra Ellen Gracie, julgado em 26.02.2007, publicado em DJ 05.03.2007. e BRASIL. Supremo Tribunal Federal. Suspensão de Segurança $n^{\circ}$ 3073, Relatora Ministra Presidente, Decisão Proferida pela Ministra Ellen Gracie, julgado em 09.02.2007, publicado em DJ 14.02.2007.

${ }_{64}$ A constatação acerca da escassez de julgados do STF é feita por: TORRES, 2009, p. 71-73; BITTENCOURT NETO, 2010, p. 96-97; HONÓRIO, 2009, p. 199 et seq.
} 
eximir-se do cumprimento de seus deveres constitucionais, sobremaneira quando dessa omissão "puder resultar nulificação ou, até mesmo, aniquilação de direitos constitucionais impregnados de um sentido de essencial fundamentalidade". ${ }^{65}$

Após lançar mão das lições de Ana Paula de Barcellos, o Ministro faz consignar a ideia de que, nada obstante a elaboração e a efetivação de políticas públicas situem-se na esfera de competência dos agentes legitimados pelas eleições populares, a liberdade de conformação do Legislativo e a esfera de discricionariedade do Executivo são limitadas, não podendo implicar omissões que comprometam a eficácia dos direitos sociais e afetem o "núcleo intangível consubstanciador de um conjunto irredutível de condições mínimas necessárias a uma existência digna e essenciais à própria sobrevivência do indivíduo", situação em que "justificar-se-á, como precedentemente já enfatizado - e até mesmo por razões fundadas em um imperativo ético-jurídico -, a possibilidade de intervenção do Poder Judiciário, em ordem a viabilizar, a todos, o acesso aos bens cuja fruição thes haja sido injustamente recusada pelo Estado". 66

Em matéria de educação, há também outras decisões de relatoria do Ministro Celso de Mello que se relacionam ao mínimo existencial e baseiam-se na fundamentação expendida na ADPF № 45. São casos que envolvem o direito fundamental das crianças com até cinco anos de idade de terem acesso à educação infantil através de creches e pré-escolas, conforme previsto no art. 208, IV da Constituição Federal. Em tais decisões, entendeu o Ministro que o mencionado direito impõe ao Estado "a obrigação constitucional de criar condições objetivas que possibilitem, de maneira concreta, em favor das 'crianças de zero a seis anos de idade' (CF, art. 208, IV), o efetivo acesso e atendimento em creches e unidades de pré-escola", situando-se fora da esfera de discricionariedade da Administração Pública a decisão em relação à

\footnotetext{
${ }^{65}$ BRASIL. Supremo Tribunal Federal. Medida Cautelar na Arguição de Descumprimento de Preceito Fundamental no 45. Relator Ministro Celso de Mello, julgado em 29.04.2004, publicado em DJ 04.05.2004.

${ }^{66}$ BRASIL. Supremo Tribunal Federal. Medida Cautelar na Arguição de Descumprimento de Preceito Fundamental no 45. Relator Ministro Celso de Mello, julgado em 29.04.2004, publicado em DJ 04.05.2004.
} 
prestação ou não desse serviço público. ${ }^{67} \mathrm{Em}$ algumas delas, o Relator fundamenta esse entendimento na necessidade de satisfação do direito em questão para assegurar as condições mínimas para o exercício da liberdade real.

Mais recentemente, embora envolvendo a mesma temática do direito fundamental à educação básica e seguindo a mesma linha das decisões anteriores, o Supremo Tribunal Federal, em acórdão da Segunda Turma (também de relatoria do Ministro Celso de Mello), desenvolveu mais aprofundadamente a fundamentação baseada no mínimo existencial para conceder o direito postulado. No julgado, afirmou-se expressamente que a reserva do possível não pode constituir óbice a satisfação judicial das prestações englobadas pelo mínimo existencial. O fundamento utilizado para identificar o direito ao mínimo existencial, considerado como verdadeira barreira ao argumento da escassez de recursos, foi o princípio da dignidade da pessoa humana. Dada a sua especificidade e pertinência com o assunto ora apreciado, justifica-se a transcrição literal da seguinte passagem da ementa do acórdão:

A destinação de recursos públicos, sempre tão dramaticamente escassos, faz
instaurar situações de conflito, quer com a execução de políticas públicas definidas
no texto constitucional, quer, também, com a própria implementação de direitos
sociais assegurados pela Constituição da República, daí resultando contextos de
antagonismo que impõem, ao Estado, o encargo de superá-los mediante opções por
determinados valores, em detrimento de outros igualmente relevantes, compelindo, o
Poder Público, em face dessa relação dilemática, causada pela insuficiência de
disponibilidade financeira e orçamentária, a proceder a verdadeiras "escolhas
trágicas", em decisão governamental cujo parâmetro, fundado na dignidade da
pessoa humana, deverá ter em perspectiva a intangibilidade do mínimo existencial,
em ordem a conferir real efetividade às normas programáticas positivadas na própria
Lei Fundamental. Magistério da doutrina. - A cláusula da reserva do possível - que
não pode ser invocada, pelo Poder Público, com o propósito de fraudar, de frustrar e
de inviabilizar a implementação de políticas públicas definidas na própria Constituição
- encontra insuperável limitação na garantia constitucional do mínimo existencial, que
representa, no contexto de nosso ordenamento positivo, emanação direta do
postulado da essencial dignidade da pessoa humana. Doutrina. Precedentes. - A

67 BRASIL. Supremo Tribunal Federal. Agravo de Instrumento oo 677.274, Relator Ministro Celso de Mello, julgado em 18.09.09, publicado em DJE 01.10.08; BRASIL. Supremo Tribunal Federal. Recurso Extraordinário no 472.707, Relator Ministro Celso de Mello, julgado em 14.03.06, publicado em DJ 04.04.06; BRASIL. Supremo Tribunal Federal. Recurso Extraordinário no 467.255, Relator Ministro Celso de Mello, julgado em 22.02.06, publicado em DJ de 14.03.06; BRASIL. Supremo Tribunal Federal. Recurso Extraordinário no 410.715, Relator Ministro Celso de Mello, julgado em 27.10.05, publicado em DJ de 08.11.05; BRASIL. Supremo Tribunal Federal. Recurso Extraordinário no 436.996, Relator Ministro Celso de Mello, julgado em 26.10.05, publicado em DJ 07.11.05. 
noção de "mínimo existencial", que resulta, por implicitude, de determinados preceitos constitucionais (CF, art. 1으. III, e art. $3^{\circ}$, III), compreende um complexo de prerrogativas cuja concretização revela-se capaz de garantir condições adequadas de existência digna, em ordem a assegurar, à pessoa, acesso efetivo ao direito geral de liberdade e, também, a prestações positivas originárias do Estado, viabilizadoras da plena fruição de direitos sociais básicos, tais como o direito à educação, o direito à proteção integral da criança e do adolescente, o direito à saúde, 0 direito à assistência social, o direito à moradia, o direito à alimentação e 0 direito à segurança. ${ }^{68}$

Outra decisão em matéria de educação, que também invocou o argumento do mínimo existencial, foi proferida pela Ministra Cármen Lúcia Antunes Rocha no Agravo de Instrumento $\mathrm{n}^{0}$ 564.035. O caso envolvia pretensão jurídica de acesso gratuito ao ensino fundamental em escola pública, diante de indeferimento de pedido de matrícula pelo Município. Lastreando-se, igualmente, na dignidade da pessoa humana, a Ministra afirmou que a negativa de vaga importava violação do mínimo existencial, na seguinte passagem: "a educação compõe o mínimo existencial, de atendimento estritamente obrigatório pelo Poder Público, dele não podendo se eximir qualquer das entidades que exercem as funções estatais. O mínimo existencial afirma o conjunto de direitos fundamentais sem os quais a dignidade da pessoa humana é confiscada". A situação não trazia maiores dificuldades, já que no caso do acesso à educação fundamental, a Constituição afirma expressamente no art. 208 , I e $§ 1^{\circ}$ se tratar de direito público subjetivo. ${ }^{69}$

Perceba-se que nessas decisões exaradas pelo Supremo Tribunal Federal não há grandes novidades, porque cuidam de prestações estatais expressamente previstas como direitos subjetivos exigíveis do Poder Público, e que claramente são imprescindíveis para assegurar aos cidadãos condições mínimas de existência digna.

Já na Ação Direta de Inconstitucionalidade № 3768, cuja relatoria também ficou a cargo da Ministra Cármen Lúcia Antunes Rocha, a ação tinha por objeto o questionamento da constitucionalidade do dispositivo do Estatuto do Idoso que prevê a gratuidade do transporte coletivo público urbano e semiurbano aos maiores de 65 anos de idade. Note-se que a disposição atacada

\footnotetext{
${ }^{68}$ BRASIL. Supremo Tribunal Federal. Agravo Regimental no Recurso Extraordinário com Agravo no 639.337, Relator Ministro Celso de Mello, Segunda Turma, julgado em 23.08.2011, DJe-177, divulgado em 14.09.2011, publicado em 15.09.2011.

69 BRASIL. Supremo Tribunal Federal. Agravo de Instrumento no 564.035, Relatora Ministra Cármen Lúcia Antunes Rocha, julgado em 30.04.07, publicado em DJ 15.05.07.
} 
simplesmente repete 0 direito consagrado pelo art. $230, \S 2^{\circ}$ da Constituição Federal. A Ministra, em seu voto, pontuou a necessidade de compatibilizar a reserva do possível, arguída pelo proponente da ação, com o mínimo existencial. ${ }^{70}$ Essa invocação, no referido caso, parece ter sido um tanto quanto exagerada, já que, embora a previsão constitucional se traduza, inegavelmente, em direito social dos idosos, não parece que a prestação em questão integre o conjunto de condições mínimas de existência digna de seus titulares. Logo, embora seja evidente a conformidade constitucional do dispositivo legal, o fundamento para tanto não reside no mínimo existencial, sob pena de se elastecer em demasia o seu conteúdo.

Há ainda uma série de outros julgados do Supremo Tribunal Federal que poderiam ser mencionados. Só no ano de 2011, há 28 decisões monocráticas que contêm a expressão "mínimo existencial". Mas em termos de decisões colegiadas, são escassos os acórdãos que lançam mão desse conceito, sendo difícil, diante disso, extrair um posicionamento sedimentado ou sistematizado da Corte a esse respeito.

Mesmo nas demais instâncias do Poder Judiciário, não se pode dizer que haja consolidada construção jurisprudencial do tema do Brasil, a não ser referências esparsas nas decisões dos tribunais que "contêm fragmentos do seu reconhecimento" (BITTENCOURT NETO, 2010, p. 96). Debruçando-se sobre o tema, Cláudia Honório cerificou que, até o ano de 2009, havia Estados que já contavam com expressiva quantidade de julgados fazendo menção ao direito sob exame, tais como São Paulo (408 casos), Minas Gerais (384), Mato Grosso do Sul (268), Rio de Janeiro (122) e Rio Grande do Sul (100). Em compensação, não encontrou qualquer referência à temática na jurisprudência de Estados como Maranhão, Piauí, Roraima e Pará (2009, p. 199). A autora identificou que os assuntos mais recorrentes são aqueles relacionados à educação, englobando acesso a creche, pré-escola e ensino fundamental, às prestações básicas de saúde, à proteção e promoção da moradia, à renda financeira mínima, à assistência judiciária e à segurança pública. Ao final da análise, conclui pela existência de uma "diversidade no tratamento conferido ao

\footnotetext{
${ }^{70}$ BRASIL. Supremo Tribunal Federal. Ação Direta de Inconstitucionalidade № 3768, Relatora Ministra Cármen Lúcia Antunes Rocha, Tribunal Pleno, julgado em 19.09.2007, DJe-131, divulgado em 25.10.2007, publicado em 26.10.2007.
} 
mínimo existencial pelos tribunais" (2009, p. 235), havendo disparidade entre aquilo que cada julgador reputa como abrangido por esse mínimo.

Não há, por conseguinte, como classificar com segurança o posicionamento do Supremo Tribunal Federal ou da jurisprudência brasileira em geral dentro das correntes divergentes identificadas no tópico anterior, acerca dos aspectos polêmicos do mínimo existencial. O que se pode afirmar, ao menos, é que os pontos de consenso na doutrina se encontram refletidos na jurisprudência: (i) o mínimo existencial pode ser deduzido do princípio da dignidade da pessoa humana; (ii) o seu reconhecimento independe de previsão normativa expressa, seja em sede constitucional ou legislativa; (iii) o seu conteúdo está intimamente relacionado com os direitos fundamentais sociais, notadamente educação e saúde; (iv) as prestações a ele inerentes podem ser exigidas individualmente perante o Poder Judiciário, reconhecendo-se-lhe caráter de direito subjetivo; (v) a sua invocação pode afastar argumentos normalmente utilizados para bloquear a satisfação judicial de direitos fundamentais sociais, tais como os princípios da separação dos poderes e da reserva legal orçamentária, bem como a reserva do possível.

Talvez apenas no que toca à sua estrutura normativa, já se possa aduzir (não sem alguma insegurança) que o Supremo Tribunal Federal tem caminhado no sentido, ainda que implicitamente, de reconhecê-lo como regra, aderindo à vertente aqui apelidada de mínimo existencial como direito definitivo. Mas quanto à definição do seu conteúdo (conteúdo determinável no caso concreto ou rol constitucional preferencial) e quanto ao seu emprego como critério de justiciabilidade de direitos econômicos e sociais (mínimo existencial como piso mínimo ou mínimo existencial como teto máximo), é ainda cedo para fazer qualquer afirmação peremptória.

\section{REFERÊNCIAS BIBLIOGRÁFICAS}

ABRAMOVICH, Víctor; COURTIS, Christian. Los derechos sociales como derechos exigibles. 2. ed. Madrid: Trotta, 2004.

ALEMANHA. BVerwGE 1, 159 (161 e ss.), 24.06.1954.

ALEXY, Robert. Teoría de los derechos fundamentales. 2. ed. Madrid: Centro de Estudios Políticos y Constitucionales, 2007. 
AMARAL, Gustavo. Direitos, escassez e escolha: em busca de critérios jurídicos para lidar com a escassez de recursos e as decisões trágicas. Rio de Janeiro: Renovar, 2001.

ANDRADE, José Carlos Vieira de. Os direitos fundamentais na Constituição Portuguesa de 1976. 3. ed. Coimbra: Almedina, 2004.

ARANGO, Rodolfo; LEMAITRE, Julieta. Jurisprudencia constitucional sobre el derecho al mínimo vital. Bogotá: Ediciones Uniandes - Facultad de Derecho de la Universidad de los Andes, 2000.

BARCELLOS, Ana Paula de. A eficácia jurídica dos princípios constitucionais: o princípio da dignidade da pessoa humana. 3. ed. Rio de Janeiro: Renovar, 2011.

BARCELLOS, Ana Paula de. O direito a prestações de saúde: complexidades, mínimo existencial e o valor das abordagens coletiva e abstrata. In: Cláudio Pereira de Souza Neto; Daniel Sarmento (Coords.). Direitos sociais: fundamentos, judicialização e direitos sociais em espécie. Rio de Janeiro: Lumen Juris, 2008.

BARCELLOS, Ana Paula de. O mínimo existencial e algumas fundamentações: John Rawls, Michael Walzer e Robert Alexy. In: Ricardo Lobo Torres (Org.). Legitimação dos direitos humanos. Rio de Janeiro: Renovar, 2002.

BARROSO, Luís Roberto. A doutrina brasileira da efetividade. In: Temas de Direito Constitucional. Rio de Janeiro: Renovar, 2005.

BARROSO, Luís Roberto. O direito constitucional e a efetividade das suas normas. 8. ed. Rio de Janeiro: Renovar, 2006.

BITTENCOURT NETO, Eurico. O direito ao mínimo para uma existência digna. Porto Alegre: Livraria do Advogado, 2010.

BRASIL. Superior Tribunal de Justiça. Recurso Ordinário no Mandado de Segurança no 6.564/RS, Rel. Ministro Demócrito Reinaldo, Primeira Turma, julgado em 23.05.1996, DJ 17.06.1996.

BRASIL. Supremo Tribunal Federal. Ação Direta de Inconstitucionalidade no 3768, Relatora Ministra Cármen Lúcia Antunes Rocha, Tribunal Pleno, julgado em 19.09.2007, DJe-131, divulgado em 25.10.2007, publicado em 26.10.2007.

BRASIL. Supremo Tribunal Federal. Agravo de Instrumento no 564.035, Relatora Ministra Cármen Lúcia Antunes Rocha, julgado em 30.04.07, publicado em DJ 15.05.07.

BRASIL. Supremo Tribunal Federal. Agravo de Instrumento № 677.274, Relator Ministro Celso de Mello, julgado em 18.09.09, publicado em DJE 01.10.08. 
BRASIL. Supremo Tribunal Federal. Agravo Regimental no Recurso Extraordinário com Agravo o 639.337, Relator Ministro Celso de Mello, Segunda Turma, julgado em 23.08.2011, DJe-177, divulgado em 14.09.2011, publicado em 15.09.2011.

BRASIL. Supremo Tribunal Federal. Medida Cautelar na Arguição de Descumprimento de Preceito Fundamental no 45. Relator Ministro Celso de Mello, julgado em 29.04.2004, publicado em DJ 04.05.2004.

BRASIL. Supremo Tribunal Federal. Medida Cautelar na Petição no 1246 , Presidente Ministro Sepúlveda Pertence, Decisão Proferida pelo Ministro Celso de Mello, julgado em 31.01.1997, publicado em DJ 13.02.1997.

BRASIL. Supremo Tribunal Federal. Recurso Extraordinário no 198.263, Relator Ministro Sydney Sanches, julgado em 12.02.2001, publicado em DJ 30.03.2001.

BRASIL. Supremo Tribunal Federal. Recurso Extraordinário no 342.413, Relatora Ministra Ellen Gracie, julgado em 14.10.2004, publicado em DJ 09.11.2004.

BRASIL. Supremo Tribunal Federal. Recurso Extraordinário no 410.715, Relator Ministro Celso de Mello, julgado em 27.10.05, publicado em DJ de 08.11.05.

BRASIL. Supremo Tribunal Federal. Recurso Extraordinário no 436.996, Relator Ministro Celso de Mello, julgado em 26.10.05, publicado em DJ 07.11.05.

BRASIL. Supremo Tribunal Federal. Recurso Extraordinário o 467.255, Relator Ministro Celso de Mello, julgado em 22.02.06, publicado em DJ de 14.03.06.

BRASIL. Supremo Tribunal Federal. Recurso Extraordinário o 472.707, Relator Ministro Celso de Mello, julgado em 14.03.06, publicado em DJ 04.04.06.

BRASIL. Supremo Tribunal Federal. Suspensão de Segurança oㅡ 3073, Relatora Ministra Presidente, Decisão Proferida pela Ministra Ellen Gracie, julgado em 09.02.2007, publicado em DJ 14.02.2007.

BRASIL. Supremo Tribunal Federal. Suspensão de Tutela Antecipada no 91, Relatora Ministra Presidente, Decisão Proferida pela Ministra Ellen Gracie, julgado em 26.02.2007, publicado em DJ 05.03.2007.

BRASIL. Tribunal de Justiça do Estado do Rio de Janeiro. Mandado de Segurança no 220/98, Rel. Del. Antonio Lindberg Montenegro, julgado em 17. 12.1998.

BRASIL. Tribunal de Justiça do Estado do Rio Grande de Sul. Agravo de Instrumento no 70013407242, 3a Câmara Cível, Rel. Des. Rogério Gesta Leal, julgado em 12.01.2006. 
BRASIL. Tribunal de Justiça do Estado do Rio Grande de Sul. Agravo de Instrumento no 70013844980, 3aㅡ Câmara Cível, Rel. Des. Rogério Gesta Leal, julgado em 16.03.2006.

CLÈVE, Clèmerson Merlin. A eficácia dos direitos fundamentais sociais. In: Romeu Felipe Bacellar Filho; Daniel Wunder Hachem (Coords.). Globalização, Direitos Fundamentais e Direito Administrativo: novas perspectivas para o desenvolvimento econômico e socioambiental. Belo Horizonte: Fórum, 2011.

CLÈVE, Clèmerson Merlin; FREIRE, Alexandre Reis Siqueira. Algumas notas sobre colisão de direitos fundamentais. In: Sérgio Sérvulo da Cunha; Eros Roberto Grau (Orgs.). Estudos de Direito Constitucional em homenagem a José Afonso da Silva. São Paulo: Malheiros, 2003.

CRUZ, Álvaro Ricardo de Souza. Regras e princípios: por uma distinção normoteorética. Revista da Faculdade de Direito da UFPR, № 45, Curitiba: SER/UFPR, p. 37-73, 2006.

DWORKIN, Ronald. Levando os direitos a sério. 3. ed. São Paulo: Martins Fontes, 2010.

FLORES, Joaquín Herrera. Hacia una visión compleja de los derechos humanos. In: __ (coord.). El vuelo de Anteo: derechos humanos y crítica da la razón liberal. Bilbao: Desclée, 2000.

FRANCISCO, José Carlos. Dignidade humana, custos estatais e acesso à saúde. In: Cláudio Pereira de Souza Neto; Daniel Sarmento (Coords.). Direitos sociais: fundamentos, judicialização e direitos sociais em espécie. Rio de Janeiro: Lumen Juris, 2008.

GAVARA DE CARA, Juan Carlos. Derechos fundamentales y desarrollo legislativo: la garantia del contenido esencial de los derechos fundamentales en la Ley Fundamental de Bonn. Madrid: Centro de Estudios Constitucionales, 1994.

GEBRAN NETO, João Pedro. A aplicação imediata dos direitos e garantias individuais: a busca de uma exegese emancipatória. São Paulo: Revista dos Tribunais, 2002.

HACHEM, Daniel Wunder. A aplicabilidade imediata dos direitos fundamentais na Constituição Federal de 1988: 20 anos de obscuridade nas brumas do senso comum teórico. EOS - Revista Jurídica da Faculdade de Direito, v. 4, p. 102-127, 2008.

HACHEM, Daniel Wunder. Mandado de injunção e direitos fundamentais: uma construção à luz da transição do Estado Legislativo ao Estado Constitucional. Belo Horizonte: Fórum, 2012. 
HACHEM, Daniel Wunder. Princípio constitucional da supremacia do interesse público. Belo Horizonte: Fórum, 2011.

HONÓRIO, Cláudia. Olhares sobre o mínimo existencial em julgados brasileiros. 2009. 306 f. Dissertação (Mestrado em Direito) - Programa de PósGraduação em Direito, Universidade Federal do Paraná, Curitiba, 2009.

KRELL, Andreas J. Direitos sociais e controle judicial no Brasil e na Alemanha. Os (des)caminhos de um Direito Constitucional "Comparado". Porto Alegre: Sergio Antonio Fabris Editor, 2002.

LEAL, Rogério Gesta. Condições e possibilidades eficaciais dos direitos fundamentais sociais: os desafios do Poder Judiciário no Brasil. Porto Alegre: Livraria do Advogado, 2009.

LEIVAS, Paulo Gilberto Cogo. Teoria dos direitos fundamentais sociais. Porto Alegre: Livraria do Advogado, 2006.

MAGANO, Octávio Bueno. Revisão constitucional. Cadernos de Direito Constitucional e Ciência Política, № 7, São Paulo, p. 108-112, abr./jun. 1994.

MANCUSO, Rodolfo de Camargo. A ação civil pública como instrumento de controle judicial das chamadas políticas públicas. In: Edis Milaré (Coord.). Ação civil pública. São Paulo: Revista dos Tribunais, 2001.

MARÍN-BARNUEVO FABO, Diego. La protección del mínimo existencial en el IRPF. Madrid: Colex, 1996.

MAURÍCIO JR., Alceu. A revisão judicial das escolhas orçamentárias: a intervenção judicial em políticas públicas. Belo Horizonte: Fórum, 2009.

MELLO, Celso Albuquerque. A proteção dos direitos humanos sociais nas Nações Unidas. In: Ingo Wolfgang Sarlet (Org). Direitos fundamentais sociais: estudos de Direito Constitucional, Internacional e Comparado. Rio de Janeiro: Renovar, 2003.

MELLO, Celso Antônio Bandeira de. Eficácia das normas constitucionais e direitos sociais. São Paulo: Malheiros, 2010.

NOVAIS, Jorge Reis. Direitos sociais: teoria jurídica dos direitos sociais enquanto direitos fundamentais. Coimbra: Coimbra Editora, 2010.

PIOVESAN, Flávia. Proteção internacional dos direitos econômicos, sociais e culturais. In: Ingo Wolfgang Sarlet (Org). Direitos fundamentais sociais: estudos de Direito Constitucional, Internacional e Comparado. Rio de Janeiro: Renovar, 2003.

PISARELLO, Gerardo. Los derechos sociales y sus garantías: elementos para una reconstrucción. Madrid: Trotta, 2007. 
PULIDO, Carlos Bernal. El principio de proporcionalidad y los derechos fundamentales. Madrid: Centro de Estudios Políticos y Constitucionales, 2003.

PULIDO, Carlos Bernal. Fundamento, conceito e estrutura dos direitos sociais: uma crítica a 'Existem direitos sociais?' de Fernando Atria. In: Cláudio Pereira de Souza Neto; Daniel Sarmento (Coords.). Direitos sociais: fundamentos, judicialização e direitos sociais em espécie. Rio de Janeiro: Lumen Juris, 2008.

SAGGESE, Federico. El derecho a un nivel de vida adecuado. Discurso jurídico y dimensión judicial. Perspectivas desde el Derecho Constitucional y Administrativo. La Plata: Librería Editora Platense, 2009.

SARLET, Ingo Wolfgang. A eficácia dos direitos fundamentais: uma teoria geral dos direitos fundamentais na perspectiva constitucional. 10. ed. Porto Alegre: Livraria do Advogado, 2010.

SARLET, Ingo Wolfgang. Dignidade da pessoa humana e direitos fundamentais na Constituição Federal de 1988. 4. ed. Porto Alegre: Livraria do Advogado, 2006.

SARLET, Ingo Wolfgang; FIGUEIREDO, Mariana Filchtiner. Reserva do possível, mínimo existencial e direito à saúde: algumas aproximações. In: Ingo Wolfgang Sarlet; Luciano Benetti Timm (Coords.). Direitos fundamentais: orçamento e "reserva do possível". 2. ed. Porto Alegre: Livraria do Advogado, 2010.

SARMENTO, Daniel. A proteção judicial dos direitos sociais: alguns parâmetros ético-urídicos. In: Cláudio Pereira de Souza Neto; (Coords.). Direitos sociais: fundamentos, judicialização e direitos sociais em espécie. Rio de Janeiro: Lumen Juris, 2008.

SILVA, José Afonso da. A dignidade da pessoa humana como valor supremo da democracia. Revista de Direito Administrativo, № 212, Rio de janeiro, p. 8984, abr./jun. 1998.

SILVA, Virgílio Afonso da. Princípios e regras: mitos e equívocos acerca de uma distinção. Revista Latino-Americana de Estudos Constitucionais, № 1, Belo Horizonte: Del Rey, p. 607-629, jan./jun. 2003.

SOUZA NETO, Cláudio Pereira de. A justiciabilidade dos direitos sociais: críticas e parâmetros. In: ; Daniel Sarmento (Coords.). Direitos sociais: fundamentos, judicialização e direitos sociais em espécie. Rio de Janeiro: Lumen Juris, 2008.

SOUZA NETO, Cláudio Pereira de. Fundamentação e normatividade dos direitos fundamentais: uma reconstrução teórica à luz do princípio democrático. In: Celso de Albuquerque Mello; Ricardo Lobo Torres (Orgs.). Arquivos de direitos humanos. Rio de janeiro: Renovar, 2002. 
TORRES, Ricardo Lobo. A jusfundamentalidade dos direitos sociais. Revista de Direito da Associação dos Procuradores do Novo Estado do Rio de Janeiro, v. 12, Rio de Janeiro, p. 349-374, 2003.

TORRES, Ricardo Lobo. O direito ao mínimo existencial. Rio de Janeiro: Renovar, 2009.

WANG, Daniel Wei Liang. Escassez de recursos, custos dos direitos e reserva do possível na jurisprudência do STF. In: Ingo Wolfgang Sarlet; Luciano Benetti Timm (Coords.). Direitos fundamentais: orçamento e "reserva do possível". 2. ed. Porto Alegre: Livraria do Advogado, 2010. 